IZA DP No. 7726

Migration and Financial Constraints:

Evidence from Mexico

Manuela Angelucci

November 2013 


\title{
Migration and Financial Constraints: Evidence from Mexico
}

\author{
Manuela Angelucci \\ University of Michigan \\ and IZA
}

\section{Discussion Paper No. 7726 \\ November 2013}

\author{
IZA \\ P.O. Box 7240 \\ 53072 Bonn \\ Germany \\ Phone: +49-228-3894-0 \\ Fax: +49-228-3894-180 \\ E-mail: iza@iza.org
}

Any opinions expressed here are those of the author(s) and not those of IZA. Research published in this series may include views on policy, but the institute itself takes no institutional policy positions. The IZA research network is committed to the IZA Guiding Principles of Research Integrity.

The Institute for the Study of Labor (IZA) in Bonn is a local and virtual international research center and a place of communication between science, politics and business. IZA is an independent nonprofit organization supported by Deutsche Post Foundation. The center is associated with the University of Bonn and offers a stimulating research environment through its international network, workshops and conferences, data service, project support, research visits and doctoral program. IZA engages in (i) original and internationally competitive research in all fields of labor economics, (ii) development of policy concepts, and (iii) dissemination of research results and concepts to the interested public.

IZA Discussion Papers often represent preliminary work and are circulated to encourage discussion. Citation of such a paper should account for its provisional character. A revised version may be available directly from the author. 
IZA Discussion Paper No. 7726

November 2013

\section{ABSTRACT}

\section{Migration and Financial Constraints: Evidence from Mexico*}

Using data collected for the evaluation of the rural component of Oportunidades, Mexico's flagship anti-poverty program, I show that poor households' entitlement to an exogenous, temporary but guaranteed income stream increases US migration even if this income is mainly consumed and that some households likely use the entitlement to this income stream as collateral to finance the migration. The individuals who start migrating because of this income shock belong to households with no counterfactual US migrants, come from the middle of the local predicted wage distribution, and worsen migrant skills. These results suggest that financial constraints to international migration are binding for poor Mexicans, some of whom would like to migrate but cannot afford to. If generalizable, they indicate that, as growth and anti-poverty and micro-finance programs relax financial constraints for the poor, Mexican migration to the US will increase and higher levels of border enforcement will likely be needed.

JEL Classification: J61, O12, O15, F22

Keywords: migration, financial constraints, Mexico

Corresponding author:

Manuela Angelucci

Department of Economics

Lorch Hall

Tappan St

Ann Arbor, Ml 48109

USA

E-mail: mangeluc@umich.edu

\footnotetext{
* I would like to thank Orazio Attanasio, Charlie Brown, Christian Dustmann, Maitreesh Gathak, Kei Hirano, Seema Jayachandran, Costas Meghir, Shaun McRae, Joel Slemrod, and seminar participants at Stanford, UCL, and UCLA and the Universities of Arizona, Michigan, and Notre Dame for their useful comments.
} 


\section{Introduction}

There is a large number of Mexican immigrants in the United States - about 12 million in 2011, half of whom are undocumented (Passel et al. 2012). This paper argues that Mexican migration to the United States, especially illegal migration, would be higher, and its skill composition worse, in the absence of financial constraints for some low-skilled prospective migrants. The conjecture behind this argument is the following. The net benefits from migration are high for unskilled workers. For example, Freeman and Oostendorp (2005) and Hoefort and Hofer (2007) estimate that the ppp-adjusted US-Mexico wage ratio for an unskilled individual undertaking the same job varies between 6.57 and 7.49. ${ }^{1}$ However, US trips are costly. In the late 1990's, crossing the border cost between 250 and 1500 dollars for illegal migrants who hire a smuggler (López Castro, 1998, from a survey of six migrant smugglers from Guanajuato, Michoacán, and Tijuana). Financing these trips may be difficult for the poor, especially if they have no relatives in the US, for example because of their low saving and borrowing potential. Since poverty is inversely correlated with skills, financial constraints are more likely to prevent low-skilled than medium- or high-skilled individuals from migrating. If these constraints are relaxed for some low-skilled individuals, their rate of US migration likely increases. The new migrants should be neither the most skilled (who were not previously constrained) nor the least skilled (for whom the constraints are still binding). Rather, they should come from somewhere in the middle of the skill distribution. Relaxing these constraints might thus increase the size and worsen the skill composition of Mexican migrants in the United States. These new migrants would most likely be illegal, as the US has a minimal supply of visa for Mexican unskilled workers. Moreover, if these people had relatives who are US citizens and could sponsor them, they would likely not be constrained to begin with.

Started by Chiswick's (1978) and Borjas' (1987) seminal works, there has been a keen interest in studying the self-selection of migrants, and in particular of Mexican migrants to the United States. Borjas (e.g. 1987, 1991, 1994) predicts negative selection - i.e. that average skills are lower for migrants than non-migrants - if migrants are from countries with a higher difference in relative wages than the destination country (such as Mexican migrants to the U.S.), assuming that migration is a function of returns to skills in the home and host countries and that migration costs increase with skills. In the last few years, a number of papers questioned both assumptions. ${ }^{2}$ Besides making conceptual criticisms, these papers and others have estimated the type of migrant

\footnotetext{
${ }^{1}$ This ratio understates the actual incentives to migrate because it does not consider savings and remittances, which should be deflated in the country in which they are spent.

${ }^{2}$ Grogger and Hanson (2011) show that migration to OECD countries is a function of absolute rather than relative wage differences between the host and home countries. Chiswick (1999), Chiquiar and Hanson (2005), Orrenius and Zavodny (2005), McKenzie and Rapoport (2010), and Belot and Hatton (2012), among others, question the hypothesis that migration costs increase with skills.
} 
selection of Mexicans in the US. The findings are mixed. ${ }^{3}$ One reason for the mixed findings is data issues. ${ }^{4}$ McKenzie and Rapoport (2010) attempt to reconcile the different findings by showing how the type of selection is a function of the presence of a migration network, which lowers migration costs for low-skilled migrants. ${ }^{5}$ This is based on the idea that some prospective low-skilled migrants face financial constraints, which are relaxed by the presence of a network. ${ }^{6}$ The idea of constraints binding for some unskilled migrants has also been suggested by Chiquiar and Hanson (2005) and explicitly modeled by Belot and Hatton (2012), among others. However, while most of the empirical findings of this literature are consistent with the presence of financial constraints that bind for the low skilled, establishing a causal relationship has required the use of strong identification assumptions. ${ }^{7}$

This paper contributes to the literature in several ways. First, it tests the hypothesis that positive income shocks relax constraints to Mexican low-skilled migration to the US under weak identification assumptions. Second, it studies the mechanisms that generate this increase in migration. Third, it documents the type of migrant selection from poor, rural Mexico and shows how loosening these constraints for some low-skilled potential Mexican migrants affects the skill composition of migrants to the US. Lastly, it discusses the implications for the future size and composition of undocumented Mexican migration to the United States. To do so, it uses the data on 506 poor and marginalized rural villages from Central Mexico collected for the evaluation of Oportunidades, Mexico's flagship anti-poverty program. These data have several advantages. First, the sampled households are poor and low-skilled - a population that likely faces financial constraints. Second, I observe an exogenous income increase: to measure its benefits, the program was initially offered only in a random subset of 320 villages, between May

\footnotetext{
${ }^{3}$ Chiquiar and Hanson (2005), Orrenius and Zavodny (2005), Mishra (2007), Kaestner and Malamud (2010), and Fernández-Huertas Moraga (2011) for rural Mexico provide evidence of intermediate or positive selection. Ibarraran and Lubosky (2007), Ambrosini and Peri (2012), and Fernández-Huertas Moraga (2011) for urban Mexico find negative selection. Caponi (2006) finds a U-shaped selection.

${ }^{4}$ The US Census, used by Chiquiar and Hanson (2005), Ibarraran and Lubosky (2007), and Mishra (2007), undercounts illegal migrants and does not provide data on likely migration determinants such as cognitive ability. The different conclusions reached by these papers partly reflect their different ways of dealing with these data issues. The Mexican Migration Project data, used by Orrenius and Zavodny (2005), oversample migrants from rural areas and from states with a history of high migration. Moreover, together with the Encuesta Nacional de Empleo Trimestral (ENET), used by Fernández-Huertas Moraga (2011), these data do not provide information on current migrants whose entire household has relocated. Lastly, most of these papers focus on specific subgroups only: males (Orrenius and Zavodny (2005) and Kaestner and Malamud (2010)), first-time migrants (Kaestner and Malamud (2010) and McKenzie and Rapoport (2010)), and household heads and their sons (Orrenius and Zavodny (2005)).

${ }^{5}$ The data used in this paper do not provide information on current migrants whose entire household has relocated, and the sample includes only males.

${ }^{6}$ See also Munshi (2003) and Fernández-Huertas Moraga (2011).

${ }^{7}$ For example, the results in McKenzie and Rapoport (2010) rely on the assumption that there are no unobserved community characteristics that drive both past and current migrant.
} 
1998 and November $1999 .^{8}$ Lastly, these data do not suffer from some of the limitations of most other data used to study the selection of Mexican migrants to the US: none of the households leaves in its entirety in the time period I analyze, nor do I need to restrict the sample to males, first-time migrants, or household heads only. ${ }^{9}$

I have the following four main findings. First, in November 1998, six months after receiving the first transfers, U.S. labor migration from eligible individuals in treatment villages increases from 0.7 to $1.1 \%$. While not large in absolute level, this change in migration constitutes about a $50 \%$ increase from the counterfactual level.

Second, this migration increase is related to the loosening of financial constraints. Most of the new migrations originate from households that would have had no migrants in the absence of the program, and which are, therefore, more likely to be constrained than households that would have had US migrants regardless of the program. Moreover, US migration increases for people with intermediate skills (measured by predicted wages) within the local skill distribution. These are the people who, based on their skills, are at the margin of migrating in the counterfactual villages, that is, the group for (some of) whom the program transfers are most likely to relax financial constraints to migration. In addition, the program's exogenous income shock does not change the rate of domestic migration, which is less likely to be constrained, since migration costs are likely much lower for domestic than international trips.

Third, the evidence suggests that some of the new migrations are not financed directly by the transfers or by savings, but rather that the program causes an increase in both US labor migration and loans and, in particular, a fast growth in the joint likelihood of borrowing and migrating to the US. An important channel through which Oportunidades, therefore, seems to affect US migration is because the entitlement to the transfer - guaranteed for at least two years - enhances some households' ability to obtain loans.

Fourth, the exogenous income shock worsens the observable skill distribution of migrants. Compared to US migrants from control villages, who are disproportionately selected from the middle and the right of the predicted wage distribution, the corresponding distribution for US migrants from treatment villages is shifted to the left. This is consistent with the hypothesis that the program's positive income shock relaxes financial constraints for some low-skilled individuals, enabling them to undertake a US migration.

I conclude by estimating that the loosening of financial constraints caused by the entitlement to Oportunidades transfers lead to 3.2 to $4.6 \%$ of the observed increase in the stock of illegal Mexican migrants in the US between 1998 and 2000. While small in absolute level, this increase

\footnotetext{
${ }^{8}$ While initially not guaranteed to last beyond 1999, the program was continued and the eligibility extended to the remaining 186 villages from November 1999 onwards. The program is still ongoing and currently covers more than 5 million households - about one fifth of all Mexican households - in both rural and urban areas.

${ }^{9}$ Steckov, Winters, Stampini, and Davis (2005) and Rubalcava and Teruel (2006) also study the effects of Oportunidades on international migration. I compare the three papers' findings in Section 5.
} 
is not negligible, considering the evidence that the transfer is not spent to directly finance migrations, but rather used as collateral to raise capital.

If one is willing to generalize, these findings have broad implications for the size and composition of Mexican migration to the US, as well as for immigration policy. Access to credit for the poor - such as what micro-finance institutions provide - and anti-poverty programs may actually increase low-skilled migration. More generally, as long as relaxing financial constraints increases the benefits from migration (by enabling people with positive wage differentials to leave) more than it increases its opportunity cost (by making staying at home more appealing), more people, with lower than average skills, will leave. This migration will most likely be illegal, for lack of visa availability for the low skilled.

As financial constraints loosen, the required level of border enforcement - the cornerstone of the current US policy to limit illegal immigration - may increase. ${ }^{10}$ This is because, as long as the US-Mexico wage differentials are large, people will be able to finance a costly US migration and still reap positive net benefits. This will occur as long as migration costs are small compared to lifetime earning differentials. Understanding the interplay between financial and economic development, migration size and composition, and border enforcement is going to be crucial to design an effective immigration policy.

\section{Migration with imperfect capital markets}

Consider a continuum of individuals with different skills $s$ and two locations, "home," $h$, and "away," a. Each potential migrant may choose between living at home and having lifetime earnings with a present value of $w(s)^{h}$, or going away and having lifetime earnings with a present value of $w(s)^{a}$. Both sets of earnings grow in $s$. Migration is a function of absolute earnings differentials, $\Delta w(s)=w(s)^{a}-w(s)^{h}$, and grows with skills, consistent with the empirical evidence from Grogger and Hanson (2011). ${ }^{11}$ There are positive migration costs, $K(s)$ - such as forgone earnings, travel expenses, and costs to be smuggled across the border for illegal migrants - partly borne up-front. These costs decrease with skills in Figure 1, as in, e.g., Chiswick 1999 and Chiquiar and Hanson 2005. For example, the interest rate on a loan to fund a US migration may be rather high for low-skilled migrants because the household of origin has no collateral. ${ }^{12}$

Individuals migrate $(M=1)$ if the net benefits from migration are positive: $M=1$ if $\Delta w(s)-K(s)>0$. That is, in this setup (1) migrants are positively self-selected, as average skills

\footnotetext{
${ }^{10}$ See, e.g., Angelucci $2012 \mathrm{a}$ and Thom 2010 on the effect of border enforcement on migration costs.

${ }^{11}$ Consistent with this literature, I abstract from dynamics and general equilibrium effects and assume that migrations are permanent.

${ }^{12}$ Indeed, low-skilled migrants without collateral may simply not be offered any loan, as raising the interest rate to its market-clearing level would cause adverse selection and moral hazard. To capture this phenomenon, the cost curve in Figure 1 increases exponentially the lower the skills, although this assumption is not needed, as the results hold as long as the slope of the cost curve is lower than the slope of the wage differential curve.
} 
are higher for migrants than non-migrants and (2) the migration likelihood grows discontinuously with skills, as it is zero below a certain skill threshold and one above it. Of course, in real life one would not expect such a sharp discontinuity. Given this setup, consider the effect of an exogenous decrease in $K$, caused by the receipt of cash transfers, as shown by the lower $K$ curve in Figure $1 .^{13}$ The entitlement to cash transfers for at least two years may reduce migration costs in multiple ways: it may provide capital to directly finance the migration; it may also provide the collateral needed to make the investment less risky both for the lenders, who would therefore decrease the interest rate on a loan, and for the prospective migrant's household, which would therefore increase its incentive to have one of its members migrate and increase the demand for loans or the willingness to dissave to finance it. Regardless of the mechanism, the exogenous income increase makes the net benefits of migration positive for individuals with skills $\in\left(s^{m^{i n}} ; s^{m i n}\right]$. The individuals who start migrating because the cash transfer decreases their migration costs are worse than the average migrant but do not come from the leftmost part of the skill distribution. The bigger the number of individuals for whom the income shock relaxes financial constraints, the larger the worsening of migrant skills. The model does not predict the location of the skill threshold, which is to be determined empirically.

\section{Data}

\subsection{Features of the program Oportunidades}

I use survey data collected in September 1997, November 1998, and November 1999. Each round of data is a census of 506 poor rural villages from the Mexican states Guerrero, Hidalgo, Michoacán, Puebla, Queretaro, San Luis Potosi, and Veracruz.

The data were collected to evaluate the Mexican social program Oportunidades (formerly named PROGRESA), an ongoing anti-poverty program that targets poor Mexican households, providing grants to improve education, health, and nutrition. The 506 villages in these data were selected from the localities eligible for Phases 2-6 of the program. Therefore, they are not a random sample of rural Mexico, but supposedly a random sample of a very large subset of all the rural localities eligible for Oportunidades. ${ }^{14}$

The program's cash transfer consists of nutritional subsidies as well as scholarships for children attending the last four grades of primary school or the first three grades of secondary school. The scholarships are conditional on children attending 3rd to 9th grade, with the grant

\footnotetext{
${ }^{13}$ In Figure 1, the magnitude of the decrease in $K$ varies inversely with skills. This shift mimics the fact that the income shock used in this paper is a program that provides cash transfers to the poor. Therefore, the probability of being a program recipient decreases with $s$, so the $K$ curve shifts downwards primarily in the left tail of the skill distribution. The results hold with any downward shift of the cost curve.

${ }^{14}$ Phases 2 to 6 covered about 1.77 million rural families in the program, which, by its final phase in 2000, comprised a total of 2.6 million rural families (Coady, 2000), about $12 \%$ of Mexico's population.
} 
varying by school grade and gender of the child. Table 1 provides a breakdown of transfer size by school grade and gender. ${ }^{15}$ If a member of the household migrates, the household remains a program beneficiary. That is, the migration of older relatives of children whose schooling is subsidized does not change these children's eligibility status.

By financing education, Oportunidades may decrease the incentives to undertake a US migration for some, while, by relaxing financial constraints, it may increase these incentives for others. Therefore, the estimate of the short-term effect of Oportunidades on US migration is a lower bound of its effect through loosened financial constraints only. The program may also increase the medium-term likelihood of migration by favoring the accumulation of human capital (Caponi, 2006, and Angelucci, 2012b). However, studying this effect is beyond the scope of this paper, as I am interested in looking at financial constraints to migration only.

While the transfer is in principle conditional, its receipt is in practice unconditional for most families, in the sense that most eligible households receive the transfers without having to change their members' time allocation. This is because pre-program school enrollment is greater than $90 \%$ for primary school children and about $66 \%$ for secondary school children. I address the issue of the transfer conditionality in Section 5.

Program eligibility depends on a wealth index computed for all households using the preprogram September 1997 census of Oportunidades localities. ${ }^{16}$ There were two rounds of selection of eligible households in Oportunidades. 52 percent of households were initially classified as eligible in 1997. These are the households with the lowest wealth index. The following year, a further group of households, initially classified as ineligible, was added into the beneficiary group. However, most of this latter set of families did not receive the transfers because of administrative problems, irrespective of their compliance with the eligibility rules. Because of this, I restrict my sample to the households initially classified as eligible.

These data are suited for understanding whether some potential migrants face financial constraints for three reasons. First, they are a census of poor, marginalized villages, the setting in which one expects financial constraints to bind. The households in this sample are indeed poor: in control villages, the average monthly food consumption per adult equivalent for households eligible for Oportunidades is about 160 pesos - roughly 16 US dollars - at November 1998 prices (Angelucci and De Giorgi, 2009). Moreover, for these households food consumption amounts to $75 \%$ of total non-durable consumption. Their benefits from migration are potentially high (see, e.g., Borjas 1987, 1991, 1994).

Second, almost all the households eligible for the program receive an exogenous guaranteed

\footnotetext{
${ }^{15}$ Oportunidades has positive effects on education in the short and medium term, as documented by Schultz (2004), Todd and Wolpin (2005), Behrman, Sengupta, and Todd (2006), and Behrman, Parker, and Todd (2009), among others.

${ }^{16}$ This wealth index was created using a discriminant analysis, i.e. computing discriminant scores from a combination of wealth- and income-related variables that explain most of the variation in per-capita income. These scores are continuous and have region-specific cutoff points that separate the eligibles from the ineligibles.
} 
income stream through the program transfers. The average transfer is $22 \%$ of the income the eligible households would have had in the absence of the program.

Third, in order to evaluate the program, the transfers were offered only in a random subset of the villages, for the first 18 months of the program existence. The "treatment" villages receive the first transfers in May 1998 and the "control" villages in November 1999. This introduces a source of exogenous variation which can be exploited to show how US migration varies with exogenous increases in household resources.

Unless otherwise specified, the empirical analysis uses the initial group of eligible households. When using individual-level data, I refer to people who belong to households eligible for the program as eligible individuals.

\subsection{Migration in the sampled villages}

People migrate for different purposes - for example to study, get married, or work. I observe data on migration both before and during the program implementation. The baseline data, collected in September 1997, about a semester before the first cash transfer took place, provide information on the household members who left the household of origin in the previous 5 years, including their current location. Unfortunately there is no information on the type of migration, so one cannot separate students from marriage and labor migrants, for example. I also have data on temporary labor migrations of current household members undertaken within the previous 12 months. While I do not know the location of international migrants, I will refer to international or U.S. migration interchangeably, since the U.S. is the most likely destination for international Mexican migrants.

The November 1998 migration data also provide information on the household members who left the household of origin and are currently away. Moreover, unlike the baseline data, they also list the purpose of the ongoing migrations, grouping them into work-, marriage-, and education-related. Since this paper deals with labor migration to the United State, my key data are restricted to labor migrations, which are 85 percent of total international migrations in November 1998. While it is not obvious whether other types of migrations are limited by financial constraints or whether and how a positive income shock would affect them. In any case, this paper's findings are unchanged if one uses total US migration rather than US labor migrations as the main outcome (results available upon request). These data are collected in 1998 - after the beginning of the program but before the transfers are offered also in the control villages. I cannot use difference-in-difference estimators because I cannot match migrants across the baseline and 1998 data waves. While I could identify the people present at baseline but missing in November 1998 by comparing the baseline and 1998 household rosters, in this way I would not know why the absentees are no longer in the household (they might have moved to a different house in the village, be at the hospital, on a trip, or dead) or where they went after leaving. The 
section of the 1998 data that provides this information has no individual identifier and cannot be matched with the baseline data. Nevertheless, my empirical specifications condition on the household migration levels at baseline, as I explain in Section 4. Moreover, Table 2 shows that there is no statistically significant difference between migration rates in treatment and control villages, regardless of which subgroup of individuals I consider. This information confirms that the randomization "works," as shown in Behrman and Todd (1999).

My key outcome of interest is the net flow of labor immigrants to the US in November 1998, about 6 months after the receipt of the first transfers in treatment villages and one year before the control villages start receiving the transfers. To do so, I compare the stock of current migrants (i.e. the proportion of the population who is away) from treated and control villages. Given the absence of pre-program mean differences in migration levels between control and treatment households (which will be shown later), this is equivalent to comparing net migration flows:

$$
\begin{aligned}
S_{98}^{T}-S_{98}^{C} & =S_{97}^{T}-S_{97}^{C}+N F_{98}^{T}-N F_{98}^{C}=N F_{98}^{T}-N F_{98}^{C} \\
\text { if } \quad S_{97}^{T} & =S_{97}^{C}
\end{aligned}
$$

where $S$ and $N F$ indicate migrant stock and net flow, the subscripts refer to the relevant year and the superscripts to treatment and control group. I create a dummy variable that equals one if the individual is a US labor migrants, zero otherwise. I do the same for domestic labor migration, which I use in one of the validation exercises.

I restrict the sample in the following way. Since 95 percent of all trips in the data are undertaken by individuals between ages 14 and 40, I include in my final sample only the individuals within this age interval, discarding older and younger ones. The resulting sample contains approximately 27,000 individuals from about 11,800 eligible households in November 1998.

There is no attrition in the data from September 1997 to November 1998, as all the households in the baseline survey are also present in the November 1998 one (although there is attrition in the later data waves). However, the sample sizes vary over time because of a cohort effect some people age in and out of the relevant sample (those aged 14 to 40).

I consider the November 1998 migration data from control villages to establish basic correlations and facts about migration. These data are more relevant than the 1997 baseline data for two purposes. First, since the 1997 data do not distinguish between the various types of migration, it is not clear how much one can learn from them that is of relevance for labor migrations. Second, if migration is trending, using 1998 data is going to be more informative than using the older data.

The rates of international migration in the Oportunidades villages are very low. For example, the estimate of the intercept from Table 2 shows that the average international migration rates in control villages in November 1998 are 0.7\% among eligible individuals. These rates are lower than the national average. For example, the 2002-2005, three-year migration rates from the 
Mexican Family Life Survey (MxFLS) are 5.6 percent and 3.3 percent for men in their 20s and 30s (Kaestner and Malamud, 2010). Conversely, the 1998 US migration rates for the same groups of men from control villages are 2.3 percent and 0.5 percent. ${ }^{17}$ These low rates are consistent with the hypothesis that the poor cannot easily finance US migrations, although potentially lucrative.

\subsection{Sample skill distribution and model implications}

The data used in this paper are a sample of indigent households from 506 geographically isolated, poor rural villages. Therefore, the sample skill distribution is considerably different from the national one. Consider Table 3's first two columns, which compare the average age and schooling distribution for eligible non-migrants from the 2000 Mexican census (from Chiquiar and Hanson, 2005) and control villages in November 1998. The village residents are slightly younger and considerably less educated than the rest of the nation. The average ages are 24.7 and 24.9 for males and females in the control villages and 25.4 and 25.6 nationally. The frequency of individuals with 0 to 8 completed schooling years is almost twice as high in the villages than nationally for both males and females. This is to be expected, given that the village residents eligible for the program transfers are poorer than the average Mexican. To the extent that differences in schooling reflect broader skill differences, the sample is disproportionately drawn from the left tail of the Mexican skill distribution. Therefore, the village skill distribution likely corresponds to the left part of the graph in Figure 1. Given this skill distribution, Section 2 predicts that the skills of the average migrant should be higher than the skills of the average non-migrant, and that migration should grow discontinuously with skills. I will further discuss these predictions after comparing the age and schooling of US migrants from the villages and the US Census, which are shown in columns 3 and 4 . This comparison shows how migrants from the villages are several years younger than migrants from the Census. The average ages are 23.1 and 21.5 for males and females in the control villages and 27.7 and 28.0 nationally. Moreover, out of the village migrants $94 \%$ of males and $78 \%$ of female have up to 8 years of schooling, that is, up to incomplete middle school, while, in the Census, $37 \%$ of male and $36 \%$ of female Mexicans in the US have up to 8 years of schooling. These differences suggest that the village residents face different costs and incentives to migrate and that comparing the sample and the Census data does not help one predict the skill level for which the Oportunidades transfers likely relax financial constraints.

Comparing columns 2 and 4 of Table 3 shows that, in control villages, male and female migrants are younger than non-migrants, male migrants are disproportionately selected from the 5 to 8 schooling interval (the category which includes completed primary school), while

\footnotetext{
${ }^{17}$ These are upper bounds of the three-year rates because the respondents are asked about ongoing migrations started within the 5 previous years and they end up including trips started even earlier.
} 
female migrants are positively self-selected in education. I will compare the skill distribution of migrants and non-migrants from control villages in Section 7.

To show that migration grows discontinuously with skills, I use predicted wages as a proxy for skills. I predict wages by regressing weekly wages for the sub-sample of employed individuals on education, age (a proxy for experience), and gender. ${ }^{18}$ I choose a flexible functional form in which I create dummies for each year of age and education and I interact these two sets of variables by a gender dummy. I do not fully saturate the model because there are many empty age-by-education cells for high-education men and women. I use baseline wages, collected in September 1997, for two reasons: first, because they are predetermined and cannot be affected by the program existence; and, second, because I can then observe the wages of would-be migrants. Ideally, one would like to compare the actual wages of migrants and non-migrants before the migration took place. However, the different waves cannot be merged at the individual level because, when a person migrates, she is assigned a new individual identifier.

I then predict wages for all individuals in the sample. I consider this predicted wage a skill index. This variable has a median of 165 pesos, and the 25th and 75th percentiles are 134 and 187 pesos. ${ }^{19}$ The corresponding average hourly rate is about 4 pesos (5 pesos at 2000 prices), considerably lower than the national average of 18 pesos from the 2000 Census (Kaestner and Malamud, 2010).

The data from control villages may provide some guidance on the skill level for which financial constraints might bind, $s^{\text {min }}$. In these villages, the rates of US migration for eligible individuals by predicted wage terciles are $0.0014,0.0030$, and 0.118 in November 1998, with only the highest rate being statistically different from the previous two. ${ }^{20}$ This is consistent with the model prediction that migration increases discontinuously with skills. The statistically significant, fourfold increase in migration rates from the second to the third wage tercile suggests $s^{\text {min }}$ might be between those terciles. That is, migration in treatment villages may be expected to increase somewhere in the second tercile of the predicted wage distribution.

The theory suggests two further correlations. First, wealth is correlated to skills by assumption. Second, migration should positively correlate with wealth for two reasons: because wealth relaxes financial constraints, and because of reverse causality, with migrant remittances increasing the wealth of the household of origin. The data are consistent with these assumptions. The estimates of the correlation coefficients between wealth and education and wealth and predicted wage are positive, large -0.25 and 0.30 , respectively - and statistically different from zero.

\footnotetext{
${ }^{18}$ I have data on days worked in the previous week, as well as the average number of hours worked in a day during the previous week. Based on these variables, I can compute the hourly wage rate. However, the hourly wage is likely measured with error for people who report their monthly and annual wages, as opposed to people who report their earnings from the previous week. I use hourly wages to perform robustness checks of my main findings.

${ }^{19}$ Neither observed nor predicted wages differ statistically between control and treatment villages.

${ }^{20}$ These values are also reported in table 5 .
} 


\section{Identification and estimation of treatment effects}

In this section I define the parameters of interest in terms of potential outcomes, and discuss their identification and estimation using the Oportunidades data. Define $Y(1)_{i}$ as individual $i$ or household $i$ 's potential outcome under Oportunidades, and $Y(0)_{i}$ as the potential outcome in the absence of Oportunidades. The main outcome of interest is international labor migration, but I will also consider domestic migration and loans. For each of these outcomes, the parameter of interest is the average causal effect of Oportunidades for eligible subjects $(E=1)$ in treatment villages $\left(T_{i}=1\right)$, i.e.

$$
A T E_{s}=E\left[Y(1)_{i} \mid E_{i}=1, T_{i}=1, s\right]-E\left[Y(0)_{i} \mid E_{i}=1, T_{i}=1, s\right] .
$$

While the second conditional mean is not observed, the randomization of Oportunidades solves the missing counterfactual problem because random assignment to the treatment is independent of potential outcomes. Hence, I replace the second conditional mean with the expected outcome level in the control group. This relies on the assumption that the randomization was in fact effective and that the program has no spillover effects to control villages. ${ }^{21}$ Thus,

$$
A T E_{s}=E\left[Y(1)_{i} \mid E_{i}=1, T_{i}=1, s\right]-E\left[Y(0)_{i} \mid E_{i}=1, T_{i}=0, s\right] .
$$

The ATE has the subscript $s$ because I am actually interested in identifying and estimating these parameters for specific sub-populations, depending on the skills of different individuals, for example. Therefore, the identification assumptions must hold for each subpopulation, as well as for each outcome.

I estimate the parameters of interest by estimating the following linear probability model for eligible individuals or households:

$$
\begin{aligned}
& Y_{i}=\beta_{0}+\beta_{1} T_{i}+\beta_{2} X_{i}+u_{i} \\
& =1,0
\end{aligned}
$$

The parameter $\beta_{1}$ identifies the $A T E$. I add a set of control variables to improve the precision of the estimated effect. These variables $\left(X_{i}\right)$ are a set of individual, household, and geographic predetermined characteristics, measured at baseline except otherwise specified. They are: current age, gender, and schooling, at the individual level (excluded from regressions at the household level); age is entered as a second-order polynomial, while there are 5 schooling categories - incomplete primary, complete primary, incomplete secondary, complete secondary, and more than secondary education; household head's age, gender, literacy, ethnicity (indigenous or Hispanic); number of household children who may attend grades 3 to 6 , and 7 to 9 (based on their age);

\footnotetext{
${ }^{21}$ To the extent that there are spillover effects to neighboring control villages, they are likely to be positive (because the cost of the marginal migration likely decreases with migration rates, as in Carrington et al. 1996) and therefore this paper is estimating a lower bound of the true migration ATE.
} 
number of household members aged 0 to 7,8 to 14, 15 to 18, 19 to 21, and 22 and older; whether the household owns or uses irrigated and non-irrigated land; dummies for whether the household suffered from a series of weather shocks during the previous six months; the household wealth index used to classify eligible and ineligible households; whether the household is member of a village-based extended family, defined as having at least a degree-one relative in the village - parent, sibling, or offspring - as a separate household living in a different dwelling; wealth index and incidence of weather shocks at the extended family level; village poverty levels; region dummies. Importantly, all regressions also control for the number of household members with a spell of temporary labor migration to the US between September 1996 and 1997 and the number of current US migrants in the household in September 1997 (without distinguishing labor, marriage, and education migrations, since this information is not available in 1997). This controls for potential baseline differences in migrations rates between the control and treatment groups. However, conditioning on these baseline migration variables or not does not change the results, consistent with the evidence of no baseline differences in migration rates presented in the previous Section. ${ }^{22}$ I cluster the standard errors at the village level.

\section{Do positive income shocks increase US migration?}

I proceed to test whether exogenous income shocks caused by the program eligibility increase international labor migration using the program randomization. I first estimate the ATEs on US migration by estimating equation 1 by OLS using data from November 1998, after the program started but before it is extended to the control villages. Table 4 reports the estimates of the parameter $\beta_{1}$, which identifies the ATE. Column 1 reports the estimate of the ATE at the individual level, while column 2 show the estimate of the ATEs on the likelihood of having at least one migrant in the household.

Table 4's column 1 shows that international migration for eligible individuals in treatment villages significantly increases by about $50 \%$, compared to the migration rate in control villages. Despite being large in proportional terms, migration from these villages remains quite low: the share of international migrants increases from 0.7 to 1.1 percent and the ATE on US migration is 0.36 percentage points. Column 2 shows the estimated treatment effect on the likelihood of having at least one international migrant in the household. The estimate of this ATE is about 0.7 percentage point and statistically significant, corresponding to a $53 \%$ increase compared to control villages.

Steckov, Winters, Stampini, and Davis (2005) and Rubalcava and Teruel (2006) also study the effects of Oportunidades on international migration. However, their findings are mostly

\footnotetext{
${ }^{22}$ I condition on past household migration rather than individual migration because I cannot match individuals across the different data waves: while the household identifier is constant across waves, the person identifier within the household changes over time.
} 
not directly comparable to the present ones. Steckov et al. study all migrations, regardless of whether they are labor, education, or marriage migrations, and consider the treatment effect in November 1999, one year later than the current estimates and a period in which 50 to 80 percent of eligible households in control villages start to receive the program grants. Nevertheless, they conclude that the small and negative effect on US migration they estimate is driven primarily by non-labor migrations, while they cannot detect any statistical effect for labor migrations. This finding is consistent with the results I present in the last column of Table 4, which I describe in the following Section. Rubalcava and Teruel (2006) study the effect of the program on migration up to 6 years from its start, and find an increase in both labor and international migrations (but do not consider international labor migration in itself). Moreover, they use a different control group, as their analysis does not rely on the initial randomization.

Financial constraints are most likely to bind for individuals belonging to households with no US migrants. Households that would have had US labor migrants regardless of the program might find it relatively easier to undertake additional migrations. Therefore, if the positive income shock increases migration by relaxing financial constraints, one would expect migration to increase more at the extensive than at the intensive margin, compared to the counterfactual state. One way to test this is to compare the effect of the treatment on individual migration with its effect on the number of households with at least one US migrant. Suppose, for example, that the income shock significantly increases the number of US migrants by some quantity $x$ but the number of households with at least one US migrant does not change. This means that all the new migrations occur at the intensive margin, i.e. from households that would have had some US migrant regardless of the program, which is not fully consistent with the financial constraint hypothesis. Conversely, if the number of households with at least one US migrant also increases by $\frac{x}{2}$, at least $50 \%$ of the new migrations occur at the extensive margin, i.e. in households that would have had no migrant without the program. This figure is a lower bound to the true share of migrations from households without migrants in the counterfactual state, as, for example, two household members may undertake a migration together.

I proceed to figure out what fraction of the additional US migrations caused by Oportunidades comes from households that would have no members in the US in the absence of the program. US labor migrations for eligible households increased 1.5 times in treatment villages, as shown in the first column of Table 4. Given that there are 190 US migrants from eligible households in treatment villages, the program caused about 64 new migrations from this group. Similarly, the share of households with at least one US migrant increased 1.53 times in treatment villages, as shown in the second column of Table 4. Given that there are 131 such eligible households in treatment villages, the program caused about 46 more households to have at least one US migrant. The ratio between these two numbers is $72 \%$, indicating that almost three quarters of the additional migrations occur in households that would have had no US migrant in the absence of the program. Since this is actually a lower bound, I conclude that these findings are 
consistent with the financial constraint hypothesis.

The income shock should not increase investments that were previously unconstrained. Since domestic migration entails lower upfront costs, financial constraints are less likely to bind for domestic migration in the absence of the treatment, and therefore the effect of Oportunidades on domestic migration is likely zero. If people are substituting from domestic to international migration because of the relaxed financial constraints, the average treatment effect on domestic migration might actually be negative. Therefore, the ATE on migration within Mexico should be either zero or negative. Indeed, the third column of table 4 reports the estimated ATE for domestic migration. This ATE is -0.0033 , about an $8 \%$ drop compared to the migration rate in control villages, but not statistically different from zero. ${ }^{23}$

To further test the model implication that the exogenous income shock should increase migration only for previously-constrained individuals, I look at the effect of Oportunidades by predicted wage terciles. Before doing so, I need to account for the transfer's conditionality, which likely changes the incentives to migrate in different ways than a pure income shock. As already mentioned, the largest share of the transfer is conditional on children attending third to ninth grade. School enrollment is almost universal until sixth grade, and it declines to $66 \%$ for seventh to ninth grades. Therefore, in the absence of the program, one third of the households would not send their children to secondary school (which starts at conditional grade). For households that start sending their children to secondary school because of the program, the members' time allocation and budget might change. For example, when a household member starts going to school, the chores she was responsible for are redistributed among the rest of the household. The budget might change because often the scholarship covers only parts of the full cost of education. For example, Schultz (2004) estimates that the scholarship for seventh to ninth grades is about one half to two thirds of the age-adjusted, full-time wage. Therefore, for individuals from these households the program may change all members' migration incentives through additional mechanisms, besides from its effect on credit constraints. To account for these additional effects of the program, I exclude from the next regression all children aged up to 16 whose highest completed school grade in June 1997 was 5th or 6th and their household members. These children are likely to start 7th grade either in the 1997-1998 or 1998-1999 academic years. Their school enrollment, therefore, and their relatives' migration behavior, are likely affected by the presence of Oportunidades. Once I limit the sample in such a way, its size drops to about 15,000 . I then estimate the following equation at the individual level:

$$
m_{i}=\beta_{0}+\gamma_{1} T_{i}+\gamma_{2} w_{2 i}+\gamma_{3} w_{3 i}+\gamma_{4} T_{i} \times w_{2 i}+\gamma_{5} T_{i} \times w_{3 i}+\gamma_{6} X_{i}+\epsilon_{i} .
$$

The variables $T$ and $X$ are the treatment indicator and the additional covariates, as described in Section 4. The variables $w_{2}$ and $w_{3}$ are dummies for the second and third terciles of predicted

\footnotetext{
${ }^{23}$ There are no significant differences in domestic migration rates in control and treatment villages at baseline.
} 
wage. $^{24}$ The parameters $\gamma_{1}, \gamma_{1}+\gamma_{4}$, and $\gamma_{1}+\gamma_{5}$ identify the ATEs for the three terciles. The upper panel of Table 5 shows the estimates of these parameters. While all the estimated ATEs are positive, only the one for the second tercile is statistically significant (and significantly different from the ATE for the first tercile). This suggests that the program relaxes financial constraints for people in the middle of the predicted wage distribution. The increase in migration is large, in relative level, as migration almost triples. However, the absolute level of US migration is still very low - it increases from $0.3 \%$ to almost $0.8 \%$ for people in this tercile. ${ }^{25}$ The lower panel of Table 5 shows similar estimates, obtained by using wages predicted without household fixed effects. The pattern of selection does not change when I group individuals based on this alternative skill index.

Figure 2 confirms the findings from the previous Table using non-parametric methods. The smoothed migration rates are statistically different from each other when the $84 \%$ confidence intervals do not intersect (Knol, Pestman, and Grobbee, 2011). This occurs for values of the predicted wage that range approximately from 165 to 192 pesos. That is, migration in treatment villages is statistically different from (and is higher than) migration in control villages in the second tercile of the predicted wage distribution (which varies from 148 to 183 pesos) but not in the bottom or top terciles of this distribution. Again, the results do not vary if I use the wages predicted without adding household fixed effects.

The existing literature focuses on males and considers people aged 21 and older. As robustness checks, I estimate the ATEs for the entire sample and by wage tercile alternatively excluding women and people younger than 21. These estimates, available upon request, show that the general findings are unchanged also when considering these slightly different samples. The results do not vary also if I use predicted hourly wages rather than weekly wages.

Besides its effect on income, the program might in principle change the incentives to migrate through its effects on health and school enrollment. However, in November 1998 there is no significant difference in the share of household members who were sick in the previous 4 weeks. This share is 0.1 in both treatment and control household. This rules out that the program is, e.g., inducing parents to migrate more because they are less likely to leave their sick children behind. Moreover, the program does not cause a significant change in the school enrollment of young children that may free up time for their child minders, who could therefore migrate. This lack of sizable enrollment increase occurs because the program provides subsidies for third to ninth grades only and because the enrollment for younger children was almost $100 \%$ to begin with (Schultz, 2004). In addition, child care is typically provided by females, while U.S. labor

\footnotetext{
${ }^{24}$ I exclude age, gender, and schooling from the set of covariates when estimating heterogeneous effects by predicted wages.

${ }^{25}$ If I consider the entire sample, the ATE on US migration is not statistically significant up to wage levels of about 170 pesos, after which it becomes statistically different from zero at the $95 \%$ level. About $40 \%$ of people from eligible households have a predicted wage higher than 170.
} 
migrants are almost all males. Lastly, the evidence of long-term positive effects on migration from Rubalcava and Teruel (2006) attenuates the potential concern that the cash transfer may be anticipating the time in which a migration occur, but may not be increasing its overall size. ${ }^{26}$ All the additional program effects should actually reduce migration likelihood (the need to have periodic, though infrequent, health checks; the higher household income, which improves home conditions; the subsidized education, which increases school enrollment rates). Therefore, it is highly likely that the estimated average treatment effects are indeed caused by the positive income shock, and not by other program features.

\section{Understanding the mechanisms}

Besides showing that migration increases after experiencing positive income shocks, this experimental design is useful to understand the mechanisms that generated the observed migration increase. The new migrations may theoretically be financed by spending the transfer itself, using savings, or borrowing (or a combination of all).

One can rule out that the transfer is used to pay the migration costs for two reasons. First, the transfer is almost entirely consumed. Angelucci and De Giorgi (2009) show that the eligibles share roughly $10 \%$ of their transfer with the ineligibles, who use it to increase their food consumption. Gertler, Martinez, and Rubio-Codina (2012) estimate that consumption of eligible households increases by about $74 \%$ of the transfer and that the remainder of the transfer is used to increase asset ownership. Therefore, there is hardly any remaining income to finance the international trip. Second, very little money had been transferred by the end of 1998, the time at which I detect a significant increase in US migration.

There is no evidence that the new trips are financed through dissaving either, as the buffer stock does not decrease for eligible households. Indeed, there is some evidence that the reverse is occurring, because the stock of poultry, a commonly held commodity, increases for the eligibles in November 1998 (both findings are from Angelucci and De Giorgi, 2009). Moreover, if US migration were financed through savings, it would have a positive trend, as more and more households save enough to finance new trips over time. One would therefore expect migration in November 1999 to be higher in treatment than in control villages. ${ }^{27}$ However, the average treatment effect on US migration in November 1999 for eligible households (reported in the last column of table 4 ) is $-0.02 \%$ and not statistically different from zero at conventional significance levels. That is, the new US migrations are not financed by savings.

\footnotetext{
${ }^{26}$ In addition, one would expect Oportunidades to delay and increase future migration through its effect on human capital, and not the reverse.

${ }^{27}$ Between October and December 1999, 50 to $80 \%$ of eligible households in control villages begin to receive the program transfers, and there is by that time an understanding that the program would continue and be extended in control villages. Therefore, if the entitlement to the program is sufficient to finance the new trips, migration may increase also in control villages.
} 
If households neither use the transfer nor their savings to finance the new trips, they must increase their debt. The eligible households may use the entitlement to the cash transfer to induce lenders - shop owners, informal moneylenders, family or friends, or other people in $75 \%$ of the cases - to make them loans they would not have received otherwise, espcially since the list of beneficiaries is presented at a village-wide assembly, and hence known by all village members.

To provide further evidence about this mechanism, I use loan data, collected in November 1998. ${ }^{28}$ These data are likely measured with error (Angelucci and De Giorgi, 2009), given that one person per household provides details about the loans contracted by all current household members in the previous 6 months and that these loans are primarily informal. Besides standard recall error, two additional sources of error may bias the estimate of the loan ATE downwards. First, if the borrower is the migrant himself, the loan information is missing, as it is asked only about current household residents. ${ }^{29}$ Second, some loans to finance migrations may already have been repaid, and therefore not listed by the respondent, at the time the data are collected. Therefore, the results based on loan data should be interpreted with caution.

The evidence from the available data, nevertheless, is consistent with the findings from Table 6, which provides estimates of the average treatment effect on loans. The first column of this Table shows that, in November 1998, only 3 percent of the people in the sample belong to a household that took out a loan in the previous six months, that is, approximately since the receipt of the first transfer. The estimate of the ATE on the probability of taking out a loan is small, -0.0006, and not statistically different from zero, suggesting that the program has no significant effect on loans at the extensive margin. Therefore, I can obtain a consistent estimate of the ATE on the average loan simply by comparing the average loans of borrowers in treatment and control villages. Column 2 shows that the average loan increases by 225 pesos and this increase is statistically significant. When I group people by their predicted wage tercile, I find that the increase in loan size is concentrated in the first two terciles: columns 3 and 4 show that the ATE on household loans for people in the first and second terciles are 308 and 355 pesos, both statistically significant and corresponding to increases of 47 and 54 percent. Column 5's ATE for people in the third predicted wage tercile, however, is only 71 pesos, an 8 percent increase, and neither statistically nor economically significant.

The exercise above is slightly incorrect because the data on loans are at the household level.

\footnotetext{
${ }^{28}$ No data on loans are collected either at baseline or in November 1999. Therefore, I can test neither whether the higher loans are being taken out by households with or without a history of borrowing, nor whether the ATE on loans is no longer significantly different from zero after the households in control villages start receiving the program transfers.

${ }^{29}$ The informal nature of the loan would make the family responsible for repaying the loan on the migrant's behalf, consistent with the evidence from the Mexican Migration project (MMP134, 2012), which shows that, in one third of the cases, the family ends up paying the smuggler fees of illegal migrations undertaken by a single family member. I consider illegal migration cost data from trips undertaken in 1993-1998, selecting communities with fewer than 5000 residents from the same states as my sample.
} 
However, by looking at the individual level I can test whether the increase in loans occurs for people with different levels of predicted wages. Columns 6 and 7 show the household-level estimates of the ATEs on the likelihood of having a loan and its amount. The first estimate is small, -0.0012 , and not statistically different from zero, while the average loan increases by 220 pesos.

To draw a closer connection between migration and loans and rule out that migration and borrowing are occurring in different households, I provide three additional pieces of evidence. First, the left panel of Table 7 shows that the likelihood of having outstanding loans is 2.5 times higher in treatment than in control villages for US labor migrants (13 versus 5 percent), but identical and lower for non US labor migrants (3 percent in both treatment and control villages). Second, the right panel of Table 7 shows that, conditional on belonging to a household with outstanding loans, loans are 83 percent higher in treatment than in control villages for US labor migrants (1124 versus 612 pesos) but only 23 percent higher for non US labor migrants (954 versus 729 pesos). Indeed, the correlation coefficient between US labor migration and loan size for eligible individuals (including zero for people whose household has no outstanding loans) is 0.004 and not statistically different from zero in control villages, and 0.041 and statistically significant at the $99 \%$ confidence level in treatment villages. ${ }^{30}$

Third, since these correlations are not necessarily causal relationships, Table 8 estimates the ATEs on the joint likelihood of being a US labor migrant and belonging to a household with loans (column 1). This joint likelihood has a statistically significant $300 \%$ increase in treatment villages, changing from $0.04 \%$ in the control group to $0.16 \%$ in the treatment group, while the joint likelihood of being a US labor migrant and not belonging to a household with outstanding debt (column 2) has a statistically insignificant 35\% increase, changing from $0.68 \%$ in the control group to $0.92 \%$ in the treatment group. That is, while most of the US migrations in control villages occur from households without loans, the increase in migration in treatment villages is statistically significant only for migrations from households with loans (and proportionally much larger than the increase in migrations from households without loans). Recall, moreover, that the estimate of the ATE for migrants from households with loans is likely downward biased and the one for migrants from households without loans is likely upward biased. Table 8 also shows that, for US labor migrants, the loan size increases by $83 \%$, from 612 pesos in control villages to to 1123 pesos in treatment villages (column 3), while, for non-US labor migrants, the loan size increases only by $23 \%$, from 729 pesos in control villages to to 954 pesos in treatment villages (column 4). However, these are likely estimates of the respective ATEs because the treatment causes endogenous selection of new migrants, as I will show in the next Section.

In sum, the evidence suggests that the program transfers are neither directly spent nor saved to finance the new migrations, but rather that the program causes an increase in both US labor

\footnotetext{
${ }^{30}$ In a regression of US migration on loan size, the interaction with a treatment dummy is positive and statistically significant. Results available upon request.
} 
migration and loans and, in particular, a fast growth in the joint likelihood of borrowing and migrating to the US. An important channel through which Oportunidades, therefore, seems to affect US migration is because the entitlement to the transfer enhances some households'ability to obtain loans.

The presence of guaranteed income may affect both the supply of and demand for loans. On the supply side, the transfer entitlement may be used as collateral, lowering the risk associated with this investment, and thus reducing the interest rate on the loan (or inducing the moneylender to supply such a loan at all). On the demand side, it may make the household more willing to undertake a risky investment. The data provide indirect evidence that the presence of outstanding loans is correlated with poverty, geographic isolation, and presence of collateral. For example, households from control villages in the highest marginalization quartile - a village-level index that grows with village poverty and geographic isolation - are half as likely to have loans than households from villages in the lowest marginalization quartile, as the share of households with loans in these two groups are $1.8 \%$ and $3.6 \%$. Moreover, control village households that own land (a proxy for collateralizable wealth) are $32 \%$ more likely to have loans than landless households, the percentages for these two groups being 3.2 and $2.4 .^{31}$

As already mentioned, the loan ATE is likely underestimated. Nevertheless, one can use this estimate to compute a lower bound of the amount borrowed per US labor migrant. The program caused 64 new migrations from eligible households in treatment villages, as shown in the previous Section. Since the loan ATE is 220 pesos and there are 208 households with outstanding loans in treatment villages, as shown in the last column of Table 6, the total increase in borrowing amounts to about 715 pesos per migrant, roughly 70 dollars. ${ }^{32}$ The average monthly transfer is 200 pesos. As such, the increase in borrowing per migrant is approximately equivalent to 3.5 months worth of transfers, or, since the program is initially guaranteed to last for two years, the increase in borrowing per migrant is about 15 percent of the total increase in collateral. Recall that hiring a smuggler to cross the border illegally costs between 250 and 1500 USD in 1997 and most illegal migrants hire a smuggler (López Castro, 1998). Since the smugglers surveyed by López Castro are mainly located in different Mexican states, I use also the Mexican Migration Project (MMP134) to compute illegal migration costs by considering migrations started in 19931998 data from small communities from the same states as my sample. I find that the median cost of hiring a smuggler to cross the border illegally is 600 dollars for a person crossing alone and that only a third of solo migrants hire a smuggler. That is, the median smuggler cost per solo migrant is 200USD. Compared with the lower-bound estimate of 70 dollars per migrant, these numbers suggest that loans cover at least one third of the crossing costs. Indeed, the migration

\footnotetext{
${ }^{31}$ Land property rights in Mexico's ejidos are such that land is an unlikely collateral to obtain loans (Valsecchi 2001; de Janvry, Emerick, Gonzalez-Navarro, Sadoulet 2012).

${ }^{32}$ Coincidentally, the estimated loan per migrant is the same if one considers the average loan size for households in treatment villages with US labor migrants and outstanding loans.
} 
costs may be paid in installments - a part upfront, another part upon safe delivery, and the remaining part while the migrants works, consistent with some of the evidence documented by López Castro (1998).

\section{Financial constraints and self-selection}

The model predicts that an exogenous income increase allows some previously-constrained, lowskilled individuals to migrate. Since the people for whom the cash transfer relaxes financial constraints have lower skills than the average migrant, the exogenous income increase worsens the migrant skill distribution, as shown in Figure 1. To test this hypothesis, I compare the distribution of predicted wages for US migrants and non-migrants in treatment and control villages. Besides testing this hypothesis, this exercise is useful also to infer the type of migrant selection that occurs in the sample, which I proceed to discuss first. I start by providing visual evidence of the differences in skill distributions in Figure 3 and then proceed to test for this difference non-parametrically in Table 9. In the Appendix, I also look at both the two marginal distributions of age and education separately and the joint education-by-age distribution.

Figure 3 has four panels. Each panel shows the predicted wage distribution for three different groups: non-migrants from control villages, US migrants from control villages, and US migrants from treatment villages. The upper left panel provides the main results, as it shows the distribution for eligible households only and uses the predicted wages generated adding household fixed effects. The remaining panels are robustness checks. The right panels use the entire sample, in case the program has spillover effects on the size and composition of ineligible households. The lower panels use the wage predicted with household fixed effect, to check whether the selection pattern changes depending on the variables used to predict wages. The data include all village residents aged 14 to 40, except all households with children aged up to 16 who had completed fifth or sixth grade by June 1997. As usual, I omit these households to control for the likely effect of the program on the time allocation of households with secondary school children, which might affect US migration in additional ways besides its effect on income and financial constraints.

Consider the upper left panel of Figure 3. Comparing the predicted wage distributions for non-migrants from control villages (solid grey line) and migrants from control villages (dashed grey line) provides evidence on the type of migrant selection. In control villages, the migrant predicted wage distribution is shifted to the right, has more mass around its middle, and a thinner left tail than the non-migrant distribution. That is, US migrants are positively selfselected, compared to the non-migrants from their village of residence.

Comparing the predicted wage distributions for US migrants from control and treatment villages (the dashed grey line and the dot-dashed black line) shows that the skill distribution is shifted to the left for migrants from treatment villages, compared to migrants from control villages. That is, the presence of Oportunidades worsens the skill distribution of international 
migrants. As financial constraints are relaxed, US migrants become more negatively self-selected.

The findings that US migrants are positively selected and that the eligibility to the program worsens their skill distribution are apparent also when I include all village residents, including ineligible households, as shown by the right panel of Figure 3. To control for other skills not captured by education, age, and gender, I also predict wages adding household fixed effects. More than half the wage earners in my sample have at least one household member who is a wage earner. The within-household wage variation is statistically significantly lower than the between variation. This is consistent with skills being transmitted between household members both through nature and nurture, positive assortative mating, and household-specific labor-market effects through, e.g. connections and social networks. Indeed, the regression with household fixed effects has an adjusted R-squared of 0.56. The predicted wage with household fixed effects is highly correlated with the wages predicted without these fixed effects, as the correlation coefficient is 0.79 . The pattern of selection does not change when I use this alternative index of skills, as shown in the bottom panel of Figure 3. This is consistent with Kaestner and Malamud's (2010) finding that Mexican migrants to the US are not selected in other dimensions of skills besides education and age.

Consistent with the evidence from Figure 3, the Wilcoxon-Mann-Withney (WMW) tests, reported in Table 9, reject the null that the two samples are from identical distributions both when comparing migrants and non-migrants in control villages and when comparing migrants in control and treatment villages. This is true for eligible households only and for both eligible and ineligible households, as well as for both types of predicted wages. ${ }^{33}$

\section{Conclusions and Discussion}

This paper exploits an exogenous income variation occurring in poor rural Mexican villages to test whether financial constraints prevent some unskilled Mexican from migrating to the United States. After their household becomes entitled to a transfer, some individuals from the middle of the local skill distribution start migrating to the US. The empirical evidence suggests that the transfer, which is to a large extent spent on non-durable consumption, is not directly used to finance the new trips. Rather, its entitlement, guaranteed for two years, enables some households to fund the costly trip to the US by providing access to loans. The new migrants worsen the migrant skill distribution.

The broader implication of these findings is that, as Mexico develops a financial sector that serves the poor, such as micro-finance institutions, and as it successfully implements anti-poverty programs, increasing the wealth of the low skilled and reducing their income variation, there will likely be an intermediate phase in which US migration increases and the quality of illegal

\footnotetext{
${ }^{33}$ The only exception is when I use the predicted wage without household fixed effects and the entire sample, including ineligible households. In this case, the p-value associated with the test is 0.123 .
} 
migrants worsens, as these policies relax financial constraints for the low skilled. For example, while the current penetration of micro-finance institutions, which in 2009 had about 12,300 borrowers and a gross loan portfolio of about 3,500,000 USD (Rondon, 2010), could finance only a few thousand migrations, a growing market means that the rate of US migrations funded through micro-finance may increase in the future. More broadly, by providing the poor with a higher and more stable income, development and growth in Mexico will correspond to an initial increase in US migrations for the low skilled. Unskilled Mexican migration to the US will eventually fade out as the US-Mexico wage differentials become sufficiently small.

Moreover, the optimal level of border enforcement is a function of financial constraints. If the constraints that prevent the poor and unskilled from financing a migration are relaxed, the same level of enforcement will result in a higher inflow, as people will be able to cover the border-crossing costs and still enjoy large migration net benefits. This will occur as long as migration costs are small compared to lifetime earnings differentials.

\section{References}

[1] Angelucci, M. (2012a), "US Border Enforcement and the Net Flow of Mexican Illegal Migration," Economic Development and Cultural Change, 60(2), 311-357.

[2] Angelucci, M. (2012b), "Conditional cash transfer programs, credit constraints, and migration," LABOUR, 26(1), 124-136.

[3] Angelucci, M. and De Giorgi, G. (2009), "Indirect effects of an aid program: how do cash injections affect ineligibles' consumption," American Economic Review, 99(1), 486-508.

[4] Behrman, J.R. and Todd, P. (1999), "Randomness in the experimental samples of PROGRESA (education, health and nutrition program)", mimeo, International Food Policy Research Institute.

[5] Behrman, J.R., Parker, S., and Todd, P. (2009), "Schooling Impacts of Conditional Cash Transfers on Young Children: Evidence from Mexico," Economic Development and Cultural Change, Vol. 57, No. 3: 439-477.

[6] Behrman, J.R. and Todd, P. (2006), "Progressing through PROGRESA: An Impact Assessment of a School Subsidy Experiment in Mexico," Economic Development and Cultural Change, Vol. 54, No. 1, p.237-275.

[7] Belot, M., and Hatton, T. (2012), "Immigrant Selection in the OECD", Scand. J. of Economics 114(4), 11051128.

[8] Borjas, G. (1987), "Self-selection and the earnings of immigrants", American Economic Review, 77(4), 531-53. 
[9] Borjas, G. (1991), "Immigration and Self-Selection," In John Abowd and Richard Freeman, eds., Immigration, Trade, and the Labor Market. Chicago: University of Chicago Press, pp. 29-76.

[10] Borjas, G. (1994), "The Economics of Immigration," Journal of Economic Literature, XXXII, pp. 16671717.

[11] Caponi, V. (2006), "Heterogeneous Human Capital and Migration: Who Migrates from Mexico to the US?," Annales d'Économie et de Statistique, forthcoming.

[12] Carrington, W., Detragiache, E., and Vishwanath, T. (1996), "Migration with Endogenous Moving Costs," The American Economic Review, 86(4), 909-30.

[13] Chiquiar, D. and Hanson, G. (2005) "International Migration, Self-Selection, and the Distribution of Wages: Evidence from Mexico and the United States", Journal of Political Economy 113(2): 239-281.

[14] Chiswick, B. (1999), "Are Immigrants Favorably Self-Selected?", American Economic Review, Vol. 89, No. 2, Papers and Proceedings, pp. 181-185.

[15] Coady, D. (2000), "Final Report - The Application of Social Cost-Benefit Analysis to the Evaluation of Progresa," International Food Policy Research Institute.

[16] de Janvry, A., Emerick, K., Gonzalez-Navarro, M, and Sadoulet, E. (2012), "Certi ed to migrate: Property rights and migration in rural Mexico," unpublished manuscript, University of California at Berkeley.

[17] Djajic, S. and Milbourne, A. (1988), "A general equilibrium model of guest-worker migration", Journal of International Economics, 25, 335-51.

[18] Faini, R. and Venturini, A. (2001), "Home bias: why is migration playing a marinal role in the globalization process?", CHILD working paper, 27/2001, University of Turin.

[19] Fernandez-Huertas Moraga, J. (2011), "New Evidence on Emigrant Selection," Review of Economics and Statistics, 93(1), 72-96.

[20] Freeman, R. B., and R. H. Oostendorp (2005), "Occupational Wages Around the World." Cambridge, MA, National Bureau of Economic Research.

[21] Gaytan-Fregosos, H. and Lahiri, S. (2000), "Foreign aid and illegal immigration", Journal of Development Economics, 63(2), 515-27.

[22] Gertler, P.J., Martinez, S., and Rubio-Codina, M. (2006) "Investing Cash Transfers to Raise Long Term Living Standards," American Economic Journal: Applied Economics, 4(1): 164-92. 
[23] Grogger, J. and Hanson, G. (2011), "Income Maximization and the Selection and Sorting of International Migrants," Journal of Development Economics,95(1), 42-57.

[24] Hanson, G (2006), "Illegal Migration from Mexico to the United States," Journal of Economic Literature, 44, 869-924.

[25] Hildebrandt, N. and McKenzie, D. (2005), "The Effects of Migration on Child Health in Mexico," Economia, 6(1), 257-89.

[26] Hoefort, A. and S. Hofer, eds. (2007), "Price and Earnings: A Comparison of Purchasing Power Around the Globe," Zurich, Switzerland: Union Bank of Switzerland AG, Wealth Management Research.

[27] Kaestner, R. and Malamud, O. (2010), "Self-Selection and International Migration: New Evidence from Mexico," NBER Working Paper No. 15765.

[28] Knol, M., Pestman, W., and Grobbee, D. (2011), "The misuse of confidence inetrvals to assess effect modification," European Journal of Epidemiology, 26(4): 253-54.

[29] López Castro, G. (1998), "Coyotes and alien smuggling," in Migration between Mexico and the United States - Binational study, Vol. 3, 965-974, Morgan Printing, Austin, Texas.

[30] Massey, D. S. (1988) "Economic Development and International Migration in Comparative Perspective", Population and Development Review 14(3), 383-413.

[31] McKenzie, D. and Rapoport, H. (2007), "Network Effects and the dynamics of Migration and Inequality: Theory and Evidence from Mexico," Journal of Development Economics, 84(1), 1-24.

[32] McKenzie, D. and Rapoport, H. (2010), "Self-Selection Patterns in Mexico-U.S. Migration: The Role of Migration Networks," Review of Economics and Statistics, 92(4), 811-821.

[33] Mexican Migration Project (2009), http://mmp.opr.princeton.edu/.

[34] Munshi, K. (2003), "Networks in the Modern Economy: Mexican Migrants in the U.S. Labor Market," Quarterly Journal of Economics, 118(2): 549-597.

[35] Orrenius, Pia M. and Madeline Zavodny (2005), "Self-Selection among Undocumented Immigrants from Mexico," Journal of Development Economics, 78(1): 215-240.

[36] Passel, J., D’Vera Cohn, and Ana Gonzalez-Barrera (2012), "Net Migration from Mexico Falls to Zeroand Perhaps Less," Washington, DC: Pew Hispanic Center.

[37] Rondon, M.C., (2010), "Mexico 2009 Microfinance Analysis and Benchmarking Report," Microfinance Information Exchange (MIX), www.themix.org. 
[38] Rubalcava, L. and Teruel, G. (2006), "Conditional Public Transfers and Living Arrangements in Rural Mexico," California Center for Population Research Working paper CCPR006-06.

[39] Schultz, T. P. (2004), "School subsidies for the poor: evaluating the Mexican PROGRESA poverty program", Journal of Development Economics, 74(1), 199-250.

[40] Skoufias, E., Davies, B., and Behrman, J.R. (1999), "Final report - An evaluation of the selection of beneficiary households in the education, health and nutrition program (PROGRESA) of Mexico", mimeo, International Food Policy Research Institute.

[41] Skoufias, E., Davies, B and de la Vega, S. (1999), "Targeting the poor in Mexico: an evaluation of the selection of households into PROGRESA ", mimeo, International Food Policy Research Institute.

[42] Steckov, G., Winters, P., Stampini, M. and Davis, B. (2005), "Do conditional cash transfers influence migration? A study using experimental data from the Mexican PROGRESA program", Demography, 42(4), 769-790.

[43] Thom, K. (2010), “ Repeated Circular Migration: Theory and Evidence from Undocumented Migrants", unpublished manuscript, New York University.

[44] Todd, P. and Wolpin, K. (2006), “ Assessing the Impact of a School Subsidy Program in Mexico Using Experimental Data to Validate a Dynamic Behavioral Model of Child Schooling", American Economic Review, 96(5): 13841417.

[45] Valsecchi, M. (2011), "Land Property Rights and International Migration: Evidence from Mexico," unpublished manuscript, University of Gothenburg.

[46] Woodruff, C. and Zenteno, R. (2007), "Migration networks and microenterprises in Mexico," Journal of Development Economics, 82, 509528.

[47] Yang, D. (2008), "International Migration, Remittances, and Household Investment: Evidence from Philippine Migrants' Exchange Rate Shocks," Economic Journal, Vol. 118, pp. 591-630. 


\section{A Migrant selection: marginal distributions and parametric test - for online publication}

This Appendix compares the education and age distributions for migrants and nonmigrants in control villages and looks at how the program changes the age and education selection of migrants. To check whether these changes apply to all village residents, and not to eligible households only, and to have a larger number of migrations, it considers both eligible and inleigible households.

Figure A.1 shows the age distribution for US migrants and non-migrants from control villages. Comparing migrants and non-migrants (the dashed and solid lines) shows that migrants are disproportionately drawn from the middle of the age distribution. The migrant age distribution has thinner tails and more mass in the middle of the distribution than the non-migrant distribution. The disproportionate migration from the middle of the age distribution would appear even more extreme without trimming the data by age, as hardly any migrant is younger than 14 and older than 40 .

Next, I consider the schooling distribution. Since only $5 \%$ of the individuals in this sample have any education beyond 9th grade, and very few have any secondary education, I create 3 education categories. Category 1 is incomplete primary school; category 2 is complete primary school; category 3 is any education beyond primary. About 39,35 , and $26 \%$ of the individuals belong to each category.

Figure A.2 shows the education distribution for US migrants and non-migrants from control villages. There is positive migrant selection along this dimension, as the average schooling is higher for migrants than for non-migrants. Comparing the schooling distributions shows that US migrants are more than half as likely to have less than primary schooling than non-migrants and about $60 \%$ more likely to have completed primary school (the shares of migrants and nonmigrants with incomplete primary school are $17 \%$ and $39 \%$, while the shares with complete primary school $58 \%$ and $36 \%$ ). Conversely, there is no difference in the share of migrants and non-migrants with more than primary education.

The next step is to see how the transfer availability changes the skill distribution of US migrants. If Oportunidades relaxes financial constraints, enabling new individuals to migrate, and if the likelihood of being financial constrained is inversely proportional to skills, then the skill distribution of migrants should be worse in treatment than in control villages.

Figure A.3 provides evidence consistent with this conjecture. The left panel shows that the age distribution of migrants is more shifted to the left in treatment than in control villages. These findings are reflected in the right panel. This panel shows the difference in age densities between migrants from treatment and control difference. That is, for each age value $a$, it computes the 
difference in densities of migrants from treatment and control villages, $d(a)$ :

$$
d(a)=f(a)_{1}^{t}-f(a)_{1}^{c},
$$

where the subscript 1 refers to US migrants, while the superscripts $t$ and $c$ to treatment and control villages. Each grey dot in the figure is the corresponding value of $d$, while the solid line is the smoothed difference in densities. This density differential is mainly positive up to age 31 and negative thereafter. This confirms that Oportunidades, by relaxing financial constraints, worsens the age (and therefore experience) distribution of migrants.

Figure A.4 repeats the same exercise for education, comparing the schooling levels of migrants from treatment and control villages. The distribution of education for migrants in treatment villages has thicker tails than the distribution in control villages. That is, the program availability makes individuals without primary school and with at least some secondary education more likely to migrate, and individuals with primary school less likely to migrate.

I also consider the joint education-by-age distribution without creating a continuous skill index using predicted wages. Rather, I create 12 schooling-by-age groups in the following way. First, I group individuals by their highest education level, using the three groups described above. I then divide each group into four age categories of approximate constant size. ${ }^{34}$ The youngest, least educated individuals should have on average lower skills than the oldest (up to 40 years old), most educated individuals, or at least than higher educated individuals in their 20's, depending on whether human capital increases in age throughout or eventually declines with age.

The first two rows in each cells of Figure A.5 consider control villages only and show the share of migrants, $P(M=1)$, for each education-by-age group. If migrants were randomly drawn form the population, there would be no systematic difference between each group share and the average share of migrants in the population, $\mu$. This share is $\mu=0.015$. Migration rates are lowest - and significantly lower than the average rate - among individuals in both the least educated and youngest age groups, youngest individuals (the first cell row and column of figure A.5, in white); highest - and significantly lower than average - among people with at least primary school and in their 20's (the central cells in light grey); not significantly different from average migration rates for people in their 30's with primary school and people in their mid 20's and 30's with beyond primary school education (the three bottom right cells, in dark grey).

Insofar as age and education are positively correlated with skills (or skills first increase and then decrease with age), the data are broadly consistent with either intermediate or mildly positive migrant selection within this population. This is because migrants are disproportionately drawn from the middle of the education-by-age distribution.

\footnotetext{
${ }^{34}$ I try to obtain equal-sized cells to ensure that differences in significance between cells do not depend on their different sizes.
} 
The third row in each cell of figure A.5 computes the difference in the share of US migrants between treatment and control village residents for each education-by-age group. Consistent with theory, the transfer availability worsens the education-by-age composition of migrants. The rates of migration in treatment villages are significantly higher than in control villages for people without complete primary school and in their mid 20's and people with complete primary school aged 14 to 20 . For these groups, migration is 2.5 and 2 times as frequent in treatment than in control villages. Conversely, migration is significantly lower in treatment than control villages for people with complete primary school in their late 20's. For this group, the rate of migration in treatment villages is $40 \%$ smaller than the rate in control villages.

\section{B Treatment effects and selection by household wealth - for online publication}

This Appendix shows how the ATE of international migration varies by household wealth and it tests whether the program entitlement, by relaxing financial constraints for some individuals and households, worsens the wealth distribution of migrants, as predicted by the theory.

Wealth is endogenous to migration, primarily because migrants tend to send remittances home. Since the data to create the wealth index were collected in September 1997, this variable is endogenous to migrations started in 1997 and before, but not to migrations caused by the program. Therefore, this wealth index likely affects the treatment effect on migration in a somewhat mechanic way: if migrations started in the past sufficiently increase the wealth of the household members left behind and relax their financial constraints, then the financial constrained households are the least wealthy ones and the entitlement to the program transfers would cause migration to increase for the members of some of these households. It is not surprising, therefore, that the treatment effect on international migration is significant only for people in the lowest wealth tercile (although none of the estimated average treatment effects is statistically different from the other two). This is shown in Table B.1.

To validate the findings that the eligibility to the Oportunidades transfers changes the skill distribution by enabling previously constrained people to migrate to the US, Figure A.6 compares the 1997 wealth density for migrants from control and treatment villages for both eligible households only and the entire sample. In both cases, I account for the additional incentives caused by the program's conditional transfers by excluding 14-16 year old people with 5 or 6 years of schooling as of September 1997 and their household members. The figure shows how the distributions differ, and how the wealth distribution is shifted more to the left for migrants from treatment villages. Non-parametric tests (available upon request) confirm that the difference

between to two distributions is statistically significant at conventional levels for the sample of eligible households only and weakly significant for the entire sample. 


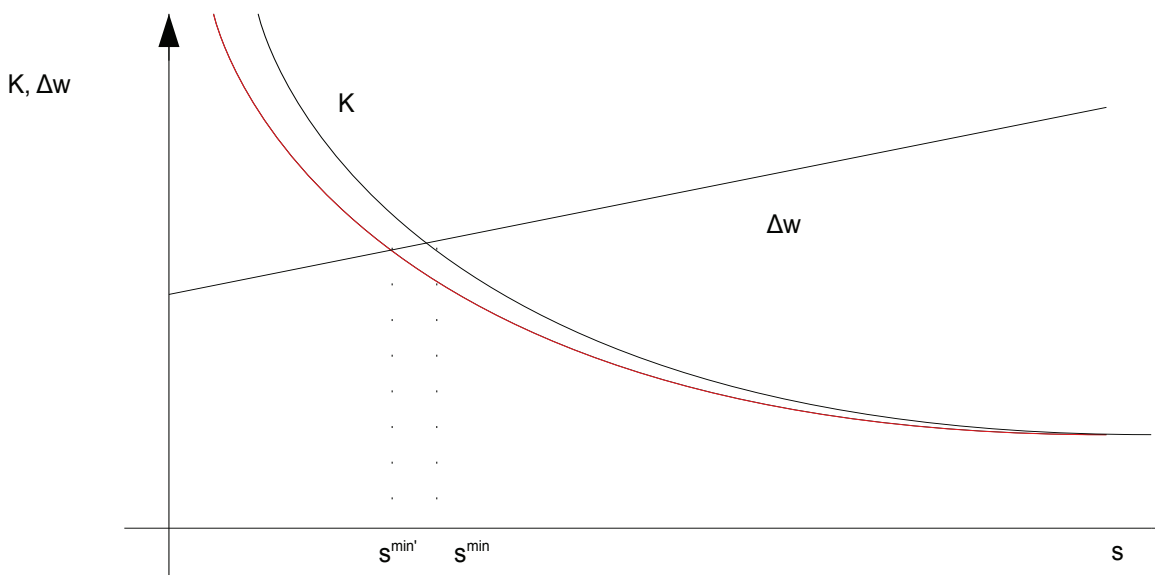

Figure 1: Wage differentials $(\Delta W)$ and migration costs $(K)$ 


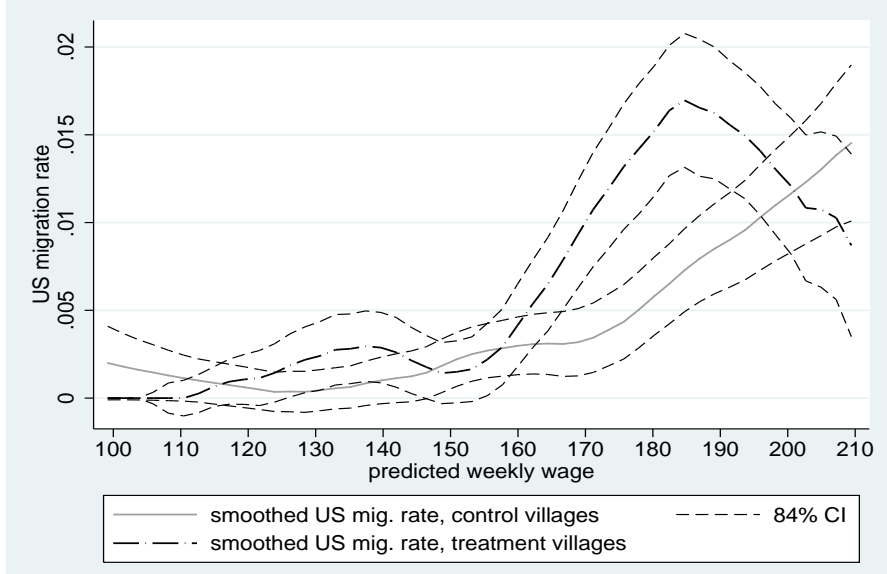

Figure 2: Local-mean smoothed US migration rates by predicted wages in control and treatment villages, November 1998 

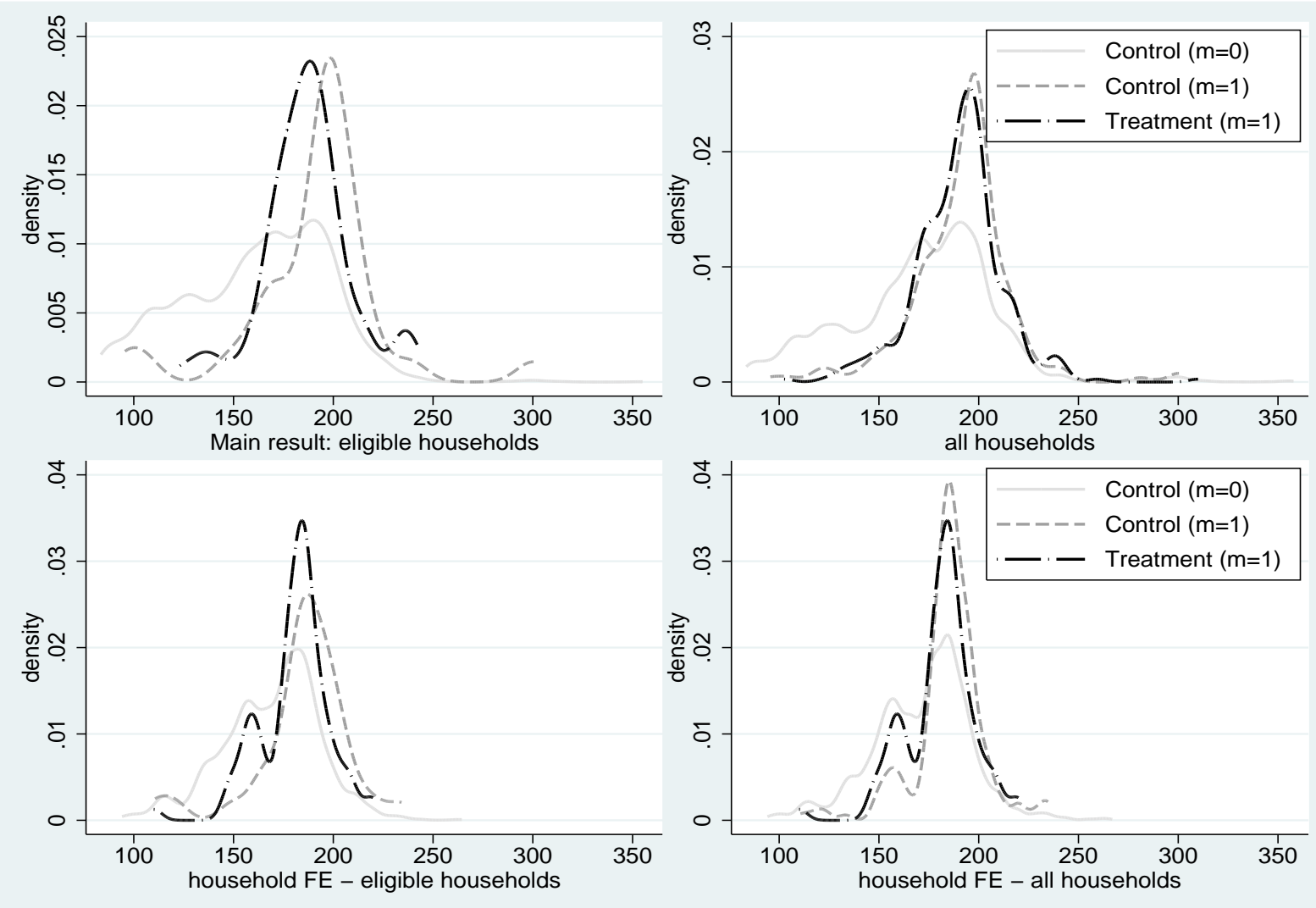

Figure 3: Predicted wage distributions for non-migrants $(\mathrm{m}=0)$ in Control villages and US migrants $(m=1)$ in Treatment and Control villages: eligible households only (left) and whole sample (right), November 1998. Wage predicted without (upper panel) and with (lower panel) household fixed effects. 


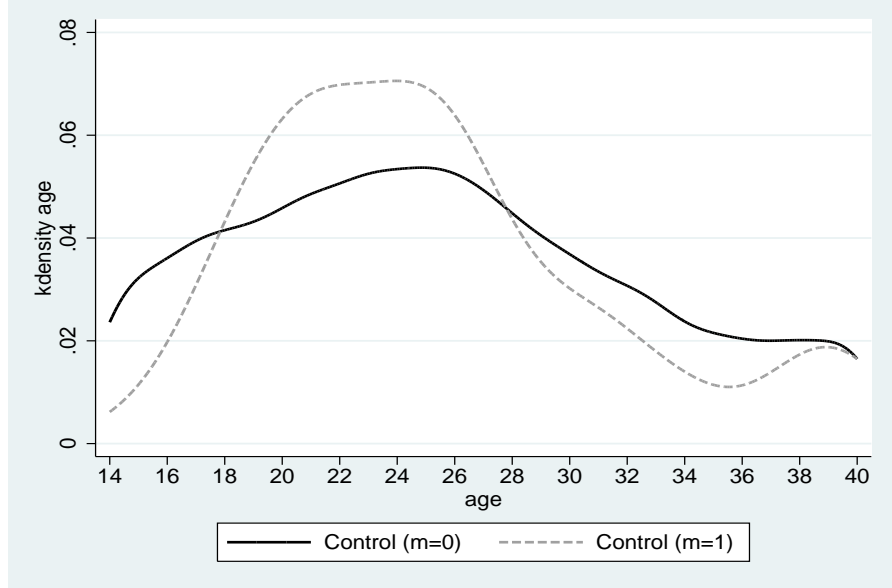

Figure A.1: Age distribution for US migrants $(\mathrm{m}=1)$ and non-migrants $(\mathrm{m}=0)$ in control villages, November 1998 


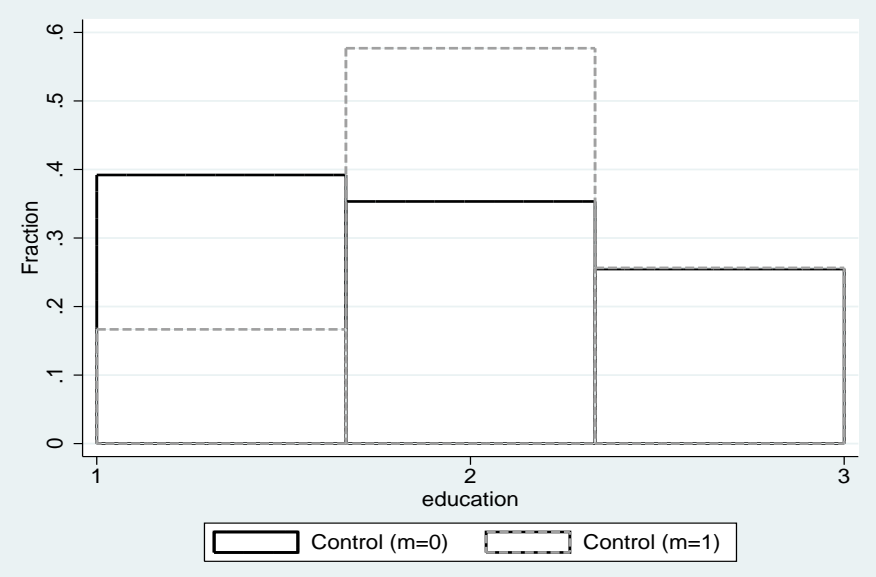

Figure A.2: Schooling distribution (incomplete primary, complete primary, more than primary education) for US migrants $(\mathrm{m}=1)$ and non-migrants $(\mathrm{m}=0)$ in control villages, November 1998 

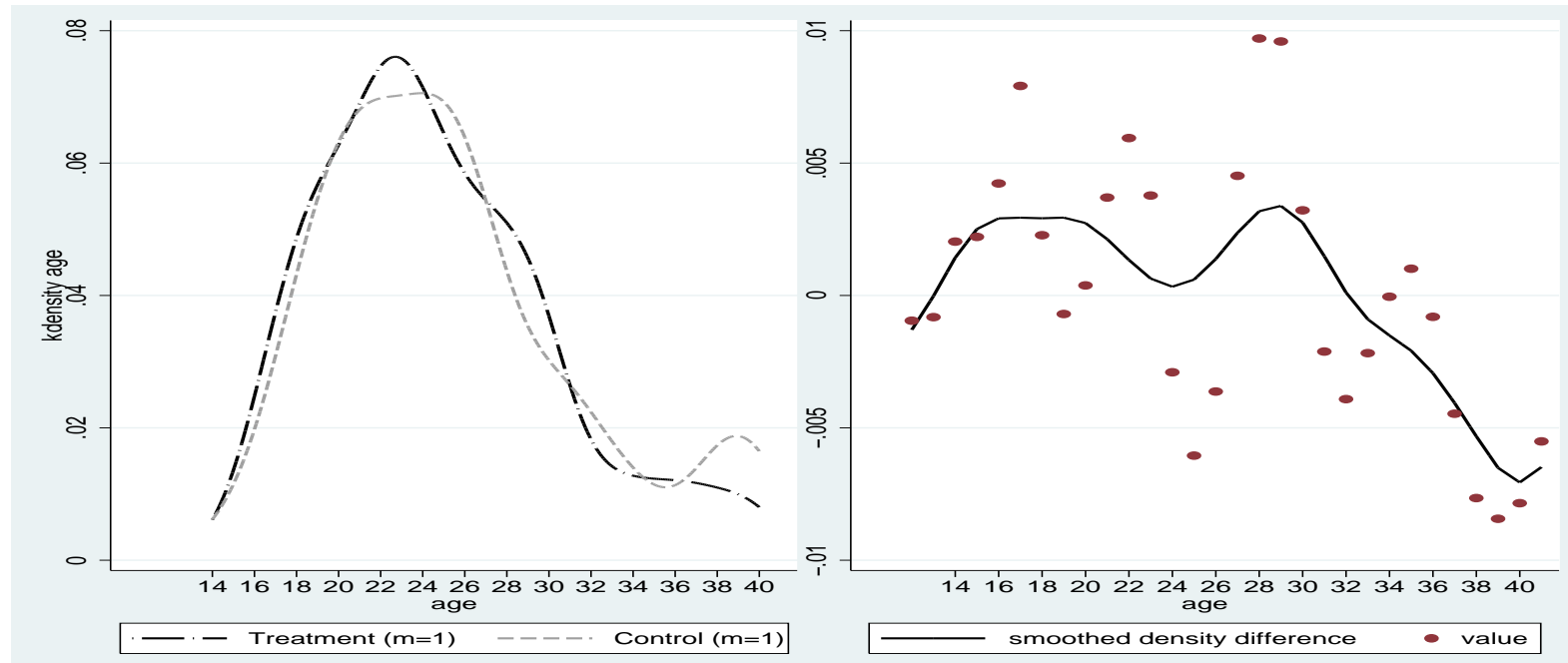

Figure A.3: Age distribution for US migrants in Treatment and Control villages (left panel) and difference in densities (right panel), November 1998 


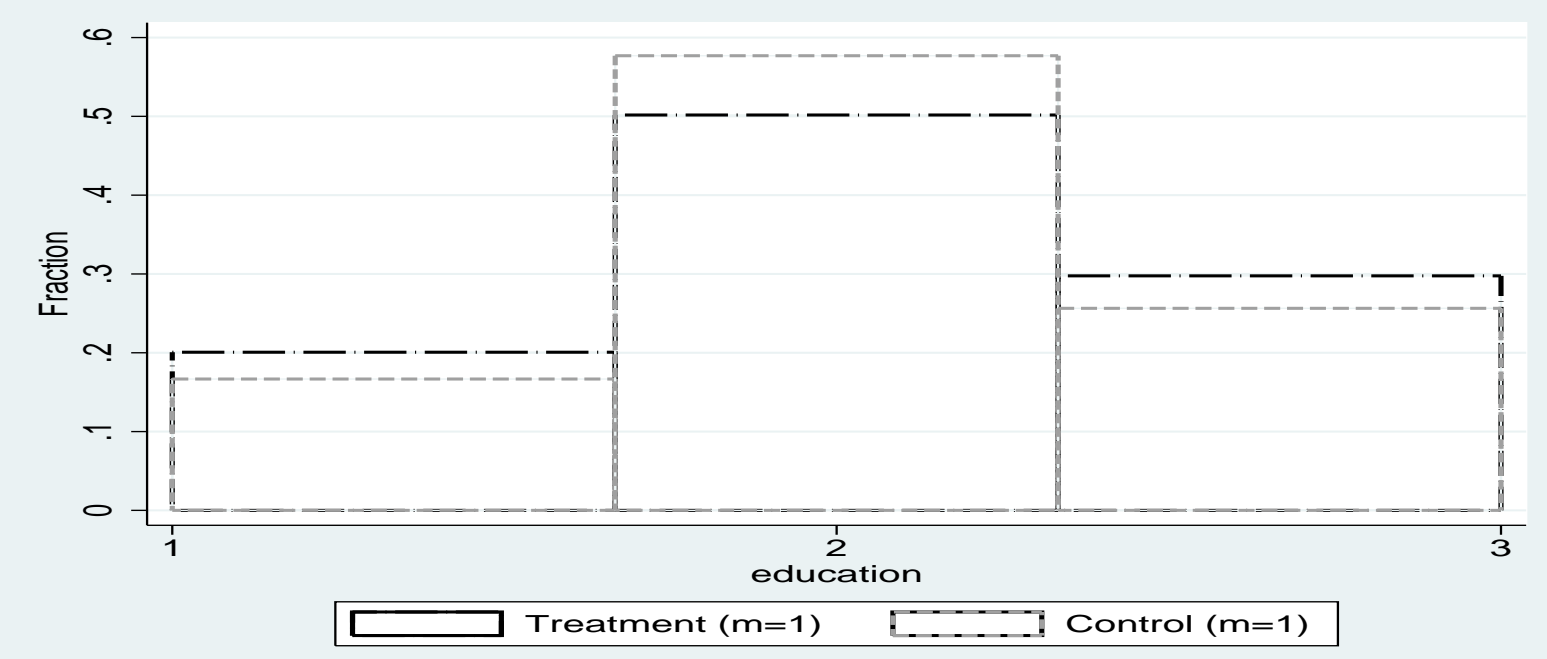

Figure A.4: Education distribution (incomplete primary, complete primary, more than primary education) for US migrants in Treatment and Control villages (right panel), November 1998 


\begin{tabular}{|c|c|c|c|c|}
\hline \multirow[t]{4}{*}{ incomplete primary } & Age $=[14 ; 22]$ & $\operatorname{Age}=[23 ; 27]$ & $\mathrm{Age}=[28 ; 33]$ & Age $=[34 ; 40]$ \\
\hline & $P(M=1)=.0069(.0025)$ & $P(M=1)=.0068(.0025)$ & $P(M=1)=.0050(.0022)$ & $\mathrm{P}(\mathrm{M}=1)=.008 \quad(.0029)$ \\
\hline & $\mathrm{HO}: \mathrm{P}(\mathrm{M}=1)=\mu \mathrm{p}=[.004]$ & $\mathrm{HO}: \mathrm{P}(\mathrm{M}=1)=\mu \mathrm{p}=[.002]$ & $\mathrm{HO}: \mathrm{P}(\mathrm{M}=1)=\mu \mathrm{p}=[.000]$ & $\mathrm{HO}: \mathrm{P}(\mathrm{M}=1)=\mu \mathrm{p}=[.017]$ \\
\hline & $\Delta \mathrm{P}(\mathrm{M}=1)=.0004(.0034)$ & $\Delta \mathrm{P}(\mathrm{M}=1)=.0097(.0049)$ & $\Delta P(M=1)=-.0025(.0036)$ & $\Delta \mathrm{P}(\mathrm{M}=1)=.008 \quad(.0029)$ \\
\hline \multirow[t]{4}{*}{ complete primary } & Age $=[14 ; 20]$ & Age $=[21 ; 24]$ & Age $=[25 ; 28]$ & Age $=[29 ; 40]$ \\
\hline & $P(M=1)=.0143(.0047)$ & $P(M=1)=.0305(.0067)$ & $P(M=1)=.0358(.0102)$ & $\mathrm{P}(\mathrm{M}=1)=.0195(.0065)$ \\
\hline & $\mathrm{HO}: \mathrm{P}(\mathrm{M}=1)=\mu \mathrm{p}=[.823]$ & $\mathrm{HO}: \mathrm{P}(\mathrm{M}=1)=\mu \mathrm{p}=[.005]$ & $\mathrm{HO}: \mathrm{P}(\mathrm{M}=1)=\mu \mathrm{p}=[.020]$ & $\mathrm{HO}: \mathrm{P}(\mathrm{M}=1)=\mu \mathrm{p}=[.447]$ \\
\hline & $\triangle P(M=1)=.0151(.0078)$ & $\Delta P(M=1)=.0066(.0087)$ & $\Delta P(M=1)=-.0159(.0084)$ & $\triangle P(M=1)=.0059(.0075)$ \\
\hline \multirow[t]{4}{*}{ beyond primary } & Age $=[14 ; 18]$ & Age $=[19 ; 22]$ & Age $=[23 ; 27]$ & $A g e=[28 ; 40]$ \\
\hline & $P(M=1)=.0054(.0026)$ & $P(M=1)=.0276(.0073)$ & $P(M=1)=.0177(.0058)$ & $P(M=1)=.0144(.0050)$ \\
\hline & $\mathrm{HO}: \mathrm{P}(\mathrm{M}=1)=\mu \mathrm{p}=[.001]$ & $\mathrm{HO}: \mathrm{P}(\mathrm{M}=1)=\mu \mathrm{p}=[.077]$ & $\mathrm{HO}: \mathrm{P}(\mathrm{M}=1)=\mu \mathrm{p}=[.662]$ & $\mathrm{HO}: \mathrm{P}(\mathrm{M}=1)=\mu \mathrm{p}=[.844]$ \\
\hline & $\Delta \mathrm{P}(\mathrm{M}=1)=.0048(.0036)$ & $\Delta P(M=1)=-.0007(.0112)$ & $\triangle P(M=1)=.0082(.0105)$ & $\Delta P(M=1)=.0025(.0058)$ \\
\hline \multicolumn{5}{|c|}{$\begin{array}{l}\text { Note: each cell represents one age-by-education group. } \mathrm{P}(\mathrm{M}=1) \text { is the share of US migration from control villages in each cell (standard error } \\
\text { clustered at the village level, in parentheses). The hypothesis } \mathrm{HO}: \mathrm{P}(\mathrm{M}=1)=\mu \text { is the null that migration in each cell is the same as the overall } \\
\text { Migration rate in control villages, } \mu \text {, which is } 0.015 . \Delta \mathrm{P}(\mathrm{M}=1)=\mathrm{E}(\mathrm{M} \mid \mathrm{T}=1)-\mathrm{E}(\mathrm{M} \mid \mathrm{T}=0 \text { ) is the difference in share of } \mathrm{S} \text { migration between treatment } \\
\text { and control villages for each cell. All tests are from regressions with standard errors clustered at the village level. This table uses data on all people } \\
\text { aged } 14 \text { to } 40 \text {, except those belonging to eligible households with members aged } 10 \text { to } 18 \text {, whose time allocation (in treatment villages) is likely } \\
\text { changed by the program participation constraints. The shaded areas approximately correspond to relatively low-skilled (white), medium-skilled } \\
\text { (light grey), and high-skilled individuals (dark grey). Italicized (bold) coefficients are significant at the } 95 \% \text { (90\%) level. }\end{array}$} \\
\hline
\end{tabular}

Figure A.5: Difference in age-by-education US migrant distribution between treatment and control villages, November 1998 

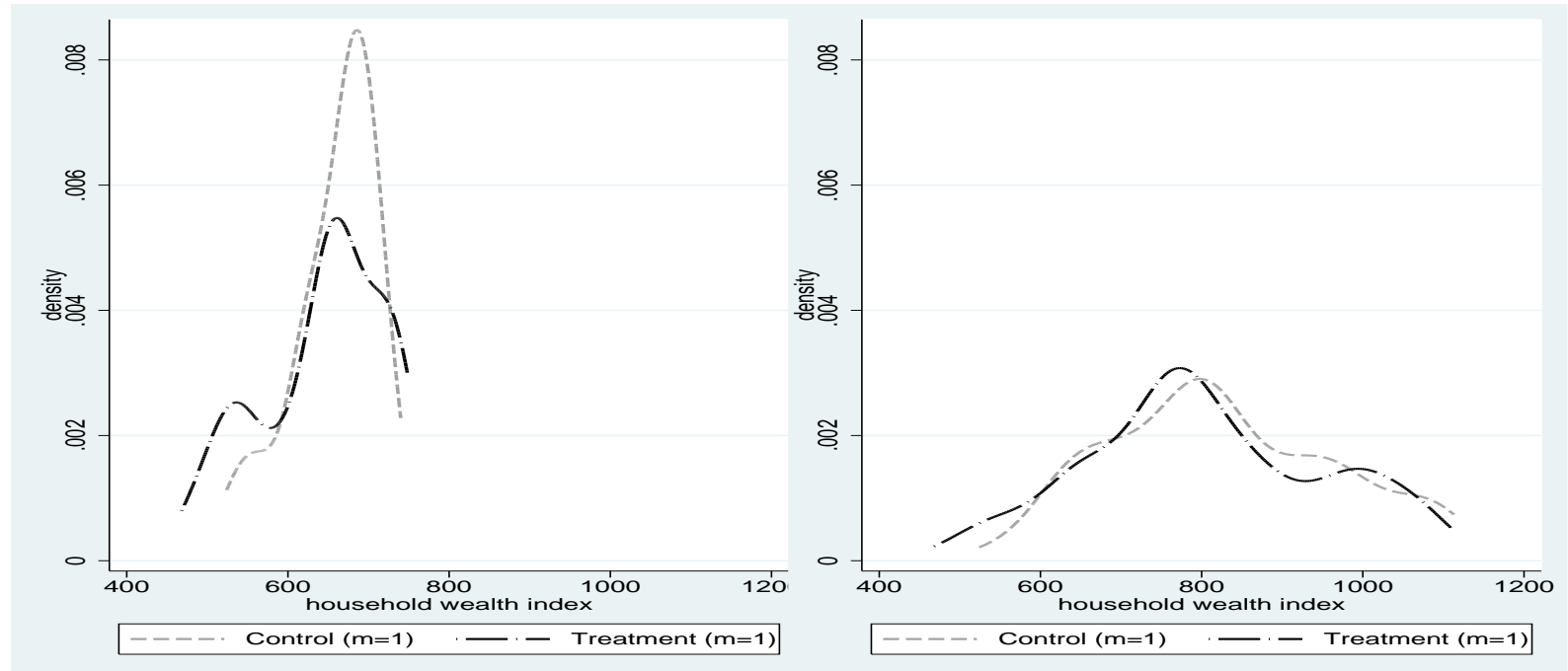

Figure A.6: Wealth distribution for US migrants in Treatment and Control villages: eligible households only (left) and whole sample (right), November 1998 
Table 1: Breakdown of program school subsidy by grade and gender

\begin{tabular}{|c|c|c|c|c|}
\hline \multirow[b]{2}{*}{ Grade } & \multicolumn{2}{|c|}{ Nov. 1998} & \multicolumn{2}{|c|}{ Nov. 1999} \\
\hline & Male & Female & Male & Female \\
\hline 3 & \multicolumn{2}{|c|}{140} & \multicolumn{2}{|c|}{160} \\
\hline 4 & \multicolumn{2}{|c|}{160} & \multicolumn{2}{|c|}{190} \\
\hline 5 & \multicolumn{2}{|c|}{200} & \multicolumn{2}{|c|}{250} \\
\hline 6 & \multicolumn{2}{|c|}{270} & \multicolumn{2}{|c|}{330} \\
\hline 7 & 400 & 410 & 480 & 500 \\
\hline 8 & 420 & 470 & 500 & 560 \\
\hline 9 & 440 & 510 & 530 & 610 \\
\hline
\end{tabular}

Bimonthly school subsidy in pesos. The average transfer is $22 \%$ of the income the eligible households would have had in the absence of the program. 
Table 2: Differences in alternative measures of migration to the US between treatment and control villages in September 1997 (at baseline) and US migration rates in control villages in November 1998.

\begin{tabular}{|c|c|c|}
\hline $\begin{array}{l}\text { Dependent } \\
\text { variable: }\end{array}$ & $Y=1$ if US migrant & $\begin{array}{c}Y=1 \text { if } \geq 1 \text { US mig. } \\
\text { in household }\end{array}$ \\
\hline \multirow[t]{2}{*}{ Unit: } & Individual & Household \\
\hline & 1 & 2 \\
\hline \multicolumn{3}{|c|}{ Pooled marriage, education, and labor migration to the US (1997) } \\
\hline \multirow[t]{2}{*}{ ATE (1997) } & 0.0021 & 0.0037 \\
\hline & {$[0.0015]$} & {$[0.0024]$} \\
\hline \multicolumn{3}{|c|}{ Control village average (1997): } \\
\hline & 0.0051 & 0.0080 \\
\hline Observations (1997) & 25607 & 10551 \\
\hline \multicolumn{3}{|c|}{ Temporary labor migration to the US (1997): } \\
\hline \multirow[t]{2}{*}{$\operatorname{ATE}(1997)$} & -0.0030 & -0.0052 \\
\hline & {$[0.0036]$} & {$[0.0082]$} \\
\hline \multicolumn{3}{|c|}{ Control village average (1997): } \\
\hline & 0.0163 & 0.0406 \\
\hline Observations (1997) & 25226 & 10551 \\
\hline \multicolumn{3}{|c|}{ Average labor migration in control villages (1998): } \\
\hline & 0.0072 & 0.0126 \\
\hline
\end{tabular}

$*, * *, * * *=$ statistically significant at the 90,95 , and 99 percent confidence level. Standard errors [in brackets] clustered at the village level. I consider individuals aged 14 to 40 only, or households with members in this age interval. All estimated regressions include the conditioning variables listed in Section 4, except for education, as the migrant schooling level is unknown at baseline. 
Table 3: Age and maximum school grade completed for Mexican non-migrants and migrants aged 14-40. Data from the Mexican and US Census (2000) and from the sample control villages (Nov. 1998)

\begin{tabular}{|c|c|c|c|c|}
\hline \multirow[b]{2}{*}{ Data from: } & \multicolumn{2}{|c|}{ Mexicans in MX (non-migrants) } & \multicolumn{2}{|c|}{ Mexicans in the US (migrants) } \\
\hline & $\begin{array}{c}\text { MX Census } \\
(\text { all, 2000) } \\
(1)\end{array}$ & $\begin{array}{c}\text { Control villages } \\
\text { (eligibles, 1998) } \\
\text { (2) }\end{array}$ & $\begin{array}{c}\text { US Census } \\
(\text { all, 2000) } \\
(3)\end{array}$ & $\begin{array}{c}\text { Control villages } \\
\text { (eligibles, 1998) } \\
\text { (4) }\end{array}$ \\
\hline \multicolumn{5}{|l|}{ Males: } \\
\hline Age & 25.4 & 24.7 & 27.7 & 23.1 \\
\hline St. Dev. & {$[7.8]$} & {$[8.2]$} & {$[6.9]$} & {$[5.7]$} \\
\hline \multicolumn{5}{|c|}{ Highest grade of schooling completed (\%): } \\
\hline 0 & 3.2 & 12.1 & 6.9 & 0.0 \\
\hline 1 to 4 & 12.5 & 30.2 & 4.0 & 19.7 \\
\hline 5 to 8 & 34.3 & 47.6 & 28.2 & 74.2 \\
\hline 9 & 22.8 & 7.8 & 11.8 & 4.6 \\
\hline 10 to 15 & 20.4 & 2.0 & 46.0 & 1.5 \\
\hline $16+$ & 6.6 & 0.2 & 2.8 & 0.0 \\
\hline Obs. & 2149498 & 4853 & 163161 & 66 \\
\hline \multicolumn{5}{|l|}{ Females: } \\
\hline Age & 25.6 & 24.9 & 28.0 & 21.5 \\
\hline St. Dev. & {$[7.7]$} & {$[7.9]$} & {$[7.0]$} & {$[7.5]$} \\
\hline \multicolumn{5}{|c|}{ Highest grade of schooling completed (\%): } \\
\hline 0 & 4.2 & 18.2 & 6.3 & 0.0 \\
\hline 1 to 4 & 13.2 & 28.1 & 3.4 & 33.3 \\
\hline 5 to 8 & 34.4 & 45.2 & 26.2 & 44.4 \\
\hline 9 & 21.1 & 7.2 & 11.8 & 22.2 \\
\hline 10 to 15 & 20.9 & 1.2 & 48.2 & 0.0 \\
\hline $16+$ & 5.9 & 0.1 & 3.8 & 0.0 \\
\hline Obs. & 2348313 & 5359 & 120556 & 9 \\
\hline
\end{tabular}

The US and Mexican 2000 Census data are from the Integrated Public Use Microdata Series. 
Table 4: effect of Oportunidades on US and domestic labor migration from eligible households, November 1998 and November 1999

\begin{tabular}{|c|c|c|c|c|}
\hline $\begin{array}{l}\text { Dependent } \\
\text { variable: }\end{array}$ & $Y=1$ if US mig. & $\begin{array}{c}Y=1 \text { if } \geq 1 \text { US mig. } \\
\text { in household }\end{array}$ & $Y=1$ if MX mig. & $Y=1$ if US mig \\
\hline Unit: & Individual & Household & Individual & Individual \\
\hline \multirow[t]{2}{*}{ Year } & 1998 & 1998 & 1998 & 1999 \\
\hline & 1 & 2 & 3 & 4 \\
\hline \multirow[t]{2}{*}{ ATE } & 0.0036 & 0.0067 & -0.0033 & -0.0024 \\
\hline & {$[0.0018]^{* *}$} & {$[0.0029]^{* *}$} & {$[0.0046]$} & {$[0.0023]$} \\
\hline \multicolumn{5}{|c|}{ Average labor migration in control villages: } \\
\hline & 0.0072 & 0.0126 & 0.0393 & 0.0109 \\
\hline Observations & 26946 & 10787 & 26920 & 22166 \\
\hline
\end{tabular}

$*, * *, * * *=$ statistically significant at the 90,95 , and 99 percent confidence level. Standard errors clustered at the village level. The reported ATEs are the OLS estimates of average treatment effect on eligible households. The number of observations varies over time because each year I consider individuals aged 14 to 40 only, or households with members in this age interval. OLS estimates from equation (1). All the estimated regressions include the conditioning variables listed in Section 4. 
Table 5: Differential effect of Oportunidades on US labor migration by predicted wage $(\hat{w})$ excluding households with conditional transfers, November 1998.

\begin{tabular}{|c|c|c|c|}
\hline Dependent & \multicolumn{3}{|c|}{$Y=1$ if US migrant } \\
\hline \multirow[t]{2}{*}{ Unit: } & \multicolumn{3}{|c|}{ Individual } \\
\hline & $1^{\text {st }} \hat{w}$ tercile & $2^{n d} \hat{w}$ tercile & $3^{r d} \hat{w}$ tercile \\
\hline \multirow{5}{*}{ ATE } & \multicolumn{3}{|c|}{ Predicted wage without household fixed effects: } \\
\hline & 0.0010 & 0.0051 & 0.0023 \\
\hline & {$[0.0014]$} & {$[0.0022]^{* *}$} & {$[0.0046]$} \\
\hline & \multicolumn{3}{|c|}{ Average migration in control villages: } \\
\hline & 0.0014 & 0.0030 & 0.0118 \\
\hline \multirow[t]{2}{*}{ Observations } & \multicolumn{3}{|c|}{15432} \\
\hline & \multicolumn{3}{|c|}{ Predicted wage with household fixed effects: } \\
\hline \multirow[t]{4}{*}{ ATE } & 0.0021 & 0.0049 & 0.0016 \\
\hline & {$[0.0015]$} & {$[0.0025]^{* *}$} & {$[0.0043]$} \\
\hline & \multicolumn{3}{|c|}{ Average migration in control villages: } \\
\hline & 0.0015 & 0.0030 & 0.0118 \\
\hline Observations & & 154 & \\
\hline
\end{tabular}

$*, * *, * * *=$ statistically significant at the 90,95 , and 99 percent confidence level. Standard errors clustered at the village level. OLS estimates. Eligible households with members aged 10 to 16 who completed 5th or 6th grade in June 1997 are omitted from the sample, because they are the group most likely to be entitled to de facto conditional transfers, which might affect the incentives to migrate. All the estimated regressions include the conditioning variables listed in Section 4 . 


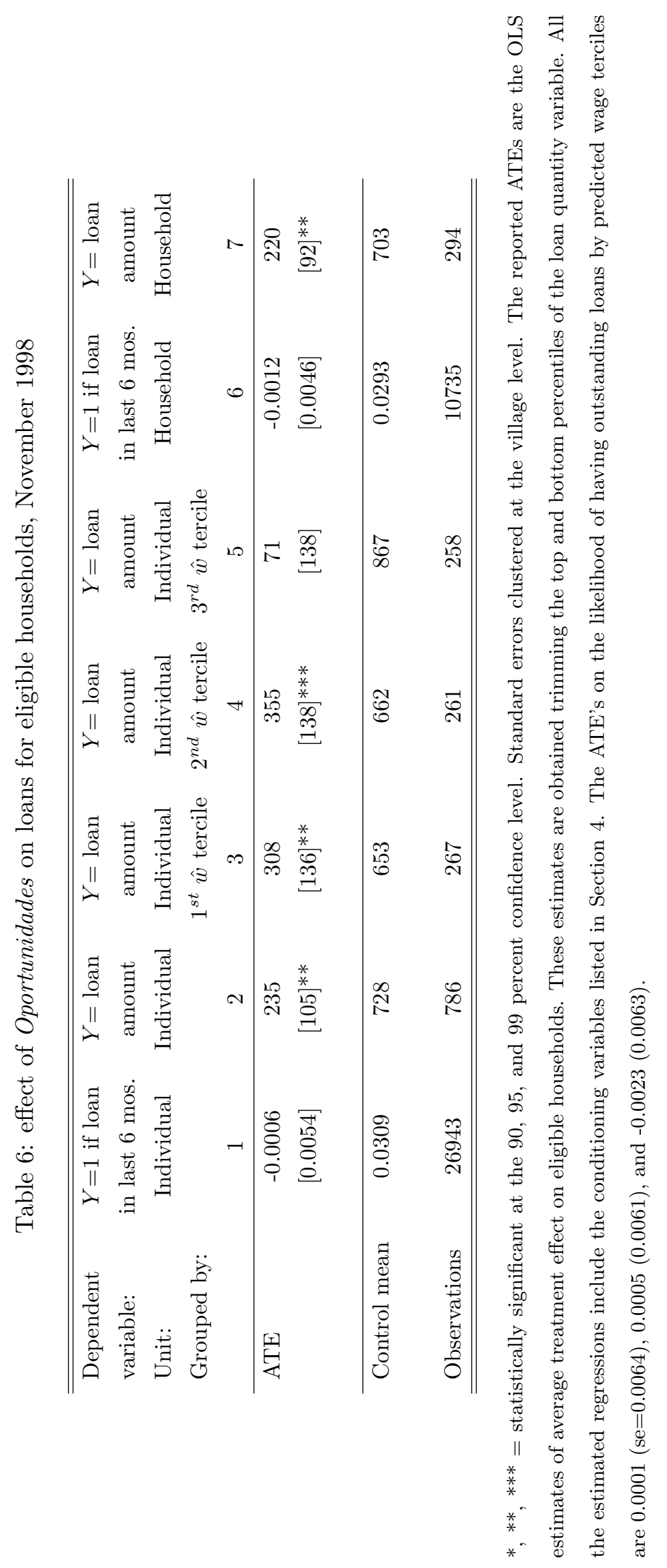


Table 7: Shares with outstanding loans and average loan for US labor migrants and non US labor migrants, November 1998

\begin{tabular}{lcc}
\hline \hline & $\begin{array}{c}\text { Percentage with } \\
\text { outstanding loans: }\end{array}$ & $\begin{array}{c}\text { Average Loan } \\
\text { (conditional on borrowing): }\end{array}$ \\
\hline US labor migrant: & 13 & 1124 \\
Treatment & 5 & 612 \\
Control & & \\
Non US labor migrant: & 3 & 954 \\
Treatment & 3 & 729 \\
Control & & \\
\hline \hline
\end{tabular}


Table 8: effect of Oportunidades on loans and migration (jointly) for eligible households, November 1998

\begin{tabular}{|c|c|c|c|c|}
\hline $\begin{array}{l}\text { Dependent } \\
\text { variable: }\end{array}$ & $\begin{array}{c}Y=\text { loan \& } \\
\text { US migrant }\end{array}$ & $\begin{array}{c}Y=\text { no loan \& } \\
\text { US migrant }\end{array}$ & $\begin{array}{c}Y=\text { loan size } \\
\text { if US migrant }\end{array}$ & $\begin{array}{c}Y=\text { loan size } \\
\text { if not US migrant }\end{array}$ \\
\hline \multirow[t]{2}{*}{ Unit: } & Individual & Individual & Individual & Individual \\
\hline & 1 & 2 & 3 & 4 \\
\hline \multirow[t]{2}{*}{ ATE } & 0.0012 & 0.0024 & 511 & 225 \\
\hline & {$[0.0006]^{*}$} & {$[0.0016]$} & {$[288]^{*}$} & {$[105]^{* *}$} \\
\hline Control mean & 0.0004 & 0.0068 & 612 & 729 \\
\hline Observations & 26943 & 26943 & 29 & 785 \\
\hline
\end{tabular}

$*, * *, * * *=$ statistically significant at the 90,95 , and 99 percent confidence level. Standard errors clustered at the village level. I consider individuals aged 14 to 40 only, or households with members in this age interval. The reported ATEs are the OLS estimates of average treatment effect on eligible households. These estimates are obtained trimming the top and bottom percentiles of the loan quantity variable. All estimated regressions include the conditioning variables listed in Section 4, except the one in column 3, which has too few observations. The differences in loan sizes conditional on migration in columns 3 and 4 are likely to be biased estimates of the ATE because the treatment causes a potentially endogenous self-selection into migration. 
Table 9: Migrant selection and skill distribution - two-sample Wilcoxon-Mann-Whitney ranksum test of equality of distributions, p-values

\begin{tabular}{|c|c|c|c|}
\hline \multicolumn{4}{|c|}{$\begin{array}{l}H_{0} \text { : the two predicted wage samples are from populations } \\
\text { with the same distributions }\end{array}$} \\
\hline \multicolumn{2}{|c|}{$\begin{array}{l}\text { Non-migrants and US migrants } \\
\text { from control villages }\end{array}$} & \multicolumn{2}{|c|}{$\begin{array}{l}\text { Migrants from treatment } \\
\text { and control villages }\end{array}$} \\
\hline Eligibles only & All sample & Eligibles only & All sample \\
\hline \multicolumn{4}{|c|}{ Predicted wage - without household fixed effects } \\
\hline 0.000 & 0.000 & 0.045 & 0.123 \\
\hline \multicolumn{4}{|c|}{ Predicted wage - with household fixed effects } \\
\hline 0.001 & 0.000 & 0.069 & 0.041 \\
\hline
\end{tabular}

Eligibles only $=$ all village residents aged 14 to 40 and member of a household eligible for the program transfers. All sample $=$ all village residents aged 14 to 40 . Eligible households with members aged 10 to 16 who completed 5th or 6th grade in June 1997 are omitted from the sample, because they are the group most likely to be entitled to de facto conditional transfers, which might affect the incentives to migrate. 
Table B.1: Differential effect of Oportunidades on US labor migration by 1997 household wealth excluding households with conditional transfers, November 1998.

\begin{tabular}{lccc}
\hline \hline $\begin{array}{l}\text { Dependent } \\
\text { variable: } \\
\text { Unit: }\end{array}$ & \multicolumn{3}{c}{$Y=1$ if US migrant } \\
& $1^{\text {st }}$ wealth tercile & $2^{\text {nd }}$ individual & \\
\hline ATE & 0.0060 & -0.0002 & 0.0030 \\
& {$[0.0029]^{* *}$} & {$[0.0042]$} & {$[0.0026]$} \\
& Average migration in control villages: & \\
& 0.0029 & 0.0086 & 0.0039 \\
& & & \\
& & 15433 & \\
Observations & & \\
\hline \hline
\end{tabular}

$*, * *, * * *=$ statistically significant at the 90,95 , and 99 percent confidence level. Standard errors clustered at the village level. OLS estimates. I consider individuals aged 14 to 40 only. Moreover, eligible households with members aged 10 to 16 who completed 5th or 6th grade in June 1997 are omitted from the sample, because they are the group most likely to be entitled to de facto conditional transfers, which might affect the incentives to migrate. All the estimated regressions include the conditioning variables listed in Section 4. 